\section{SOBRE A METAPOESIA EM PROPÉRCIO E NA POESIA ERÓTICA ROMANA: O POETA RUFIÃO*}

\author{
Paulo Martins **
}

RESUMO: Este artigo tem a preocupação de mapear a construção das personae poéticas na poesia erótica romana, entre final da República e o início do Principado, a fim de redimensionar alguns aspectos sobre o "jogo poético" que orienta programaticamente esse tipo de poesia entre a realidade e a ficção. Assim observo, de um lado, aspectos denotativos ou referenciais dessas personae poéticas - masculinas e femininas -, resgatando sua uitae modus ou sua maneira de ser, além do ambiente decoroso, adequado a essa forma mentis, a essa maneira de pensar e de agir. De outro lado, procuro revelar como estas mesmas personae devem e podem ser lidas conotativa ou poeticamente, isto é, entendidas como tropos. Dessa forma, se associamos esse aspecto das personagens poéticas àquela imagem referencial ou contextual, não só podemos ter clareza sobre o "jogo poético" a que está sujeita a recepção de poesia erótica do referido período, como também esse mesmo jogo, fronteiriço por excelência, referencia uma leitura metapoética.

PALAVRAS-CHAVE: Poesia erótica romana; elegia; metapoesia; devassidão; prostituta; rufião.

\section{ON METAPOETRY IN PROPERTIUS, AND IN ROMAN EROTIC POETRY: THE POET PIMP}

* Este artigo apresenta resultados parciais da pesquisa realizada por mim, como Visiting Fellow, junto ao departamento de Classics da Yale University, entre 2013 e 2014, financiada pela FAPESP. Agradeço a colaboração dessa Universidade que me franqueou a Classics Library no Phelps Hall, 24 horas por dia, 7 dias por semana, e também, a Sterling Library e suas "facilities". Também agradeço o apoio do meu amigo, Kirk Freudenburg, e dos colegas, Niek Jenssen, Benjamin Jerue, Collin McCaffrey e Mike Zimm do staff de Yale.

\section{**Professor Livre-Docente da Universidade de São Paulo e Bolsista Pq do CNPq. Universidade de São Paulo paulomar@usp.br}

\begin{abstract}
This paper is concerned with mapping the construction of the poetic personae in Roman erotic poetry from the late Republic and the early Principate, with a view to reevaluate some aspects of the "poetic game" which programmatically orients this kind of poetry between reality and fiction. Then, on the one hand, I observe some denotative and referential aspects of these poetic personae - both male and
\end{abstract}


female -, restoring their ways of life (uitae modus) as well as the decorous ambience, appropriate to this forma mentis, this way of thinking and acting. On the other hand, I try to reveal how these same personae can and must be read connotatively and poetically, i.e., they must be understood as tropes. Therefore, if we associate these aspects of the personae to the denotative and referential aspects, we will not only be clear about the "poetic game" to which the reception of the erotic poetry of this period was subordinate, but also that this same game, a border genre, par excellence, provides a metapoetic reading.

KEYWORDS: Erotic Roman poetry; Elegy; meta-poetry; depravity; whore; pimp.

I think that we are conscious, in Virgil more than in any other Latin poet - for Catullus and Propertius seem ruffians, and Horace somewhat plebeian, by comparison - of a refinement of manners springing from a delicate sensibility", and particularly in that test of manners, private and public conduct between the sexes.

T. S. Eliot

\section{OS AGENTES DA DEVASSIDĀO - ALGUNS REFERENTES}

${ }^{1}$ Wike (1987a); (1987b); (2002); Fear (2000); (2005); Greene (1995b); Sharrock (2000); Fantham (2009); Miller (2013).

${ }^{2}$ Veyne $(1985,10)$. $1 \begin{aligned} & \text { poesia erótica romana revela um ambiente necessário } \\ & \text { à narração de seus eventos e à caracterização de suas } \\ & \text { personae em consonância com sua textualidade. De }\end{aligned}$ um lado, já foi amplamente discutido que os agentes da poesia erótica ${ }^{1}$ cujo exemplo significativo é Propércio, em que pese a inegável importância de Catulo e, posteriormente, Ovídio, são construídos a partir de uma matriz constituída de jovens rapazes e moças de "vida irregular", ${ }^{2}$ ou ainda, de uma juventude de alto estrato social, alheia às preocupações de cunho civil e, em certa medida, em desacordo com o mos maiorum. De outro lado, eles mesmos, os jovens, estão ou submetidos a um padrão de vida boêmia, ou por si constroem seu ambiente pouco familiar, em que a conduta devassa, licenciosa e/ou luxuriosa lhes seja absolutamente decorosa e, portanto, em precisa coadunação com aquilo que são, logo, com os seus n̋ $\theta \eta$. Griffin nesse sentido afirma: 
The existence of a given pattern of conduct influences the conception which people have of the ways in which it is possible to behave or to live. If this were not so, the existence of fashions in these matters would be inexplicable. ${ }^{3}$ Indo além, mais do que uma moda, posso pensar também em gêneros poéticos, ou mesmo em séries de autores, de obras e de gêneros, cânones ou mívokes, comuns entre os antigos, ${ }^{4}$ que nada mais são, acredito, do que listas de gêneros, autores e obras cuja significação é importante ou sob ponto de vista pessoal, ou sob perspectiva de um "senso comum".

A comédia latina, por seu turno, mesmo que as prescrições do cômico potencializem os vícios, amplificandoos ao ponto da deformação, ${ }^{5}$ descortina o comportamento desses jovens romanos, atribuindo-lhes uma maneira grega de ser, isto é, no âmbito das representações literárias, comportar-se contrariamente a valores morais vigentes, é comportar-se à maneira dos gregos. A fuga dos "bons costumes" - boni mores $-{ }^{6}$ assim, se liga a liberalidades e a licenciosidades gregas que, no mais das vezes, também é restrita ao mundo helenístico - descarta-se, dessa forma, um lapso mais largo de tempo -; assim como a própria poética do período, ${ }^{7}$ que, antes de se aproximar da poética clássica, ou mesmo, arcaica, filia-se à alexandrina. ${ }^{8}$ Griffin sintetiza que é justamente esta maneira de ser - uitae modus ${ }^{9}$ - a que encontramos nos poemas de Lucílio e também em Catulo e em seus contemporâneos, isto é, uma vida de amores, festas, bebidas, ciúmes, e, para alguns, até mesmo, de poesia e música, e completa: And this is the life, one of inertia and nequitia, which the Augustan elegists proclaim as their own. And of course from an early date such a life was felt to be Greek: the meaning of congraecare and pergraecari in Plautus. ${ }^{10}$ Assim, posso afirmar que muito além da elegia helenística de Calímaco ou Filetas, é a comédia latina que oferece à elegia romana seus "heróis", já que nela, na comédia nova, frequentemente, os jovens amantes agem em contexto urbano e em suas características não encontramos a capacidade de realização de eventos especiais ou diferentes, ao contrário, suas açōes estão focalizadas em aspectos banais, triviais da vida privada, deixando de lado o universo político. ${ }^{11}$ Entretanto, por outro lado, é reconhecível o lugar institucional da "vida irregular" entre os romanos, já que a própria origem de
${ }^{3}$ Griffin $(1976,88)$.

${ }^{4}$ Quint., Inst. 10.85-131; Plin., Nat. 34.55; D.L. 8.86; Ath. 6.244a e $13.585 \mathrm{~b}$. As obras antigas seguem as abreviaturas de citação do Oxford Latin

Dictionary, daqui em diante OLD e do Greek-English Lexicon de Liddell, Scott, and Jones (LSJ). Ver Schein, S. L. (2008), Farrell (2012).

${ }^{5}$ Arist., Po. 1449a 32-36.

${ }^{6}$ Sen., Con. 2.6.

${ }^{7}$ Estabeleço como recorte temporal o nascimento de Catulo e a morte de Ovídio: 87 a.C. -18

d.C., isto é, os anos finais da República e os anos iniciais do Império e/ou Principado.

${ }^{8}$ Gibson (2005, 166).

${ }^{9}$ Prop. 1.7.9.

${ }^{10}$ Griffin (1976, 90). OLD: congraecare: To squander like a greek (Pl., Bac. 743.); OLD:

pergraecari: To behave like a greek; corouse; make merry (Pl., Mos. 64 e Poen. 603.).

${ }^{11}$ Gibson (2005, 167): Yet, for all the obviousness (to us) of the influence of Roman comedy on love elegy, there is not one explicit reference in love elegy to a Roman comic poet. The elegists were happy to give prominence instead to more prestigious Hellenistic elegists, as well as to the Greek predecessor of Plautus and Terence, Menander. 
${ }^{12}$ ver Prop. 4.1.37-38.

${ }^{13}$ Salles $(1982,172)$.

${ }^{14}$ Salles (1982, 173).

${ }^{15}$ Cic., Att. 1.19.8.

${ }^{16}$ Cic., Off. 1.106: Atque etiam, si considerare volemus, quae sit in natura excellentia et dignitas, intellegemus, quam sit turpe diffluere luxuria et delicate ac molliter vivere, quamque honestum parce, continenter, severe, sobrie. Se quisermos saber o que é a dignidade e a excelência na natureza, entendamos que é torpe ceder à luxúria e viver no luxo e na languidez - e que é honesto viver com parcimônia, continência, austeridade e fragalidade.

Tradução de Angélica Chiappetta.

${ }^{17}$ OLD: 2. Morally worthless, depraved, bad, scoundrelly; 3. Naughty, roguish (esp. in erotic context). Nequam+ia, ies = nequitia, nequies.

${ }^{18}$ Cic., Off. 1.106: Atque etiam, si considerare volemus, quae sit in natura excellentia et dignitas, intellegemus, quam sit turpe diffluere luxuria et delicate ac molliter vivere, quamque honestum parce, continenter, severe, sobrie. Se quisermos saber o que é a dignidade e a excelência na natureza, entendamos que é torpe ceder à luxúria e viver no luxo e na languidez - e que é honesto viver com parcimônia, continência, austeridade e fragalidade. Tradução de Angélica Chiappetta.
Roma associa-se ao mito de Aca Laurência, cuja relação com a prostituição é explícita. Salles propõe que "as lendas relativas a duas 'lobas', ${ }^{12}$ nas quais a falta de respeito dá as mãos ao maravilhoso, não teriam interesse para nós se não nos dessem uma representação curiosa de Roma das origens", ${ }^{13}$ ou seja, uma Roma em que a vida do bas-fonds caminha paralelamente à da moral ilibada e severa, de sorte que é possível encontrarmos entre o patriciado romano a ideia de que a busca física dos prazeres é indispensável à sociedade e, assim, a prostituição passa a ser uma "componente essencial da ordem social." 14

Outra questão que deve ser pesada é o conceito de delicata iuuenta.$^{15}$ Em uma das Catilinárias, Cícero, expondo quais são os comparsas de Catilina, enumera um rol com cinco tipos diferentes de homens viciosos, e o último deles caracteriza a própria maneira de vida de Catilina, não só pelo se vestir, pelo se pentear ou pelo se barbear, como também por representar um homem cuja principal atividade da vida se manifesta nas ceias da madrugada, na boemia, nas vigílias e no orgias do Suburra. Sobre eles termina dizendo: in his gregibus omnes aleatores, omnes impuri impudicique versantur. hi pueri tam lepidi ac delicati non solum amare et amari neque saltare et cantare, sed etiam sicas vibrare et spargere uenena didicerunt. ${ }^{16}$ Assim, os jovens afeitos à luxúria, ao sexo e ao amor são os mesmos que se ocupam da degradação política da República. Talvez a melhor forma de delinear o îtos dessa pessoa seja dizer que ele é um nequam, ${ }^{17}$ isto é, alguém sem valor cuja moralidade é desprezível, um patife, abertamente indecente, dada a sua sexualidade. Curiosamente em Cícero, a maneira de ser sob o prisma moral corrobora o posicionamento político indevido. No Sobre os Deveres, ele propóe um contraste entre modos de vida, que parece justificar as afirmações propostas no discurso. Um primeiro: parce, continenter, seuere, sobrie; e um outro, diffluere luxuria et delicate ac molliter ninere. ${ }^{18}$ Obviamente, tal construção binária remete a uma ética que opera, de um lado, vícios e, de outro, virtudes, onde estão assentadas, pois, as categorias retóricas do discurso demonstrativo. Assim as qualidades morais elevadas, para Cícero e para alguns romanos no final da República, estão imbricadas obrigatoriamente com qualidades políticas 
igualmente elevadas. Assim, hipoteticamente, quem venha a defender a República romana, seguramente não irá defender uma maneira grega de ser. Parece-me que tal "regulagem" comportamental e política vaza para o campo poético-retórico a que Cícero se refere no Orator quando faz crítica aos poetae noui ${ }^{19}$ ou mesmo, as Tusculanas ${ }^{20}$ ao usar a expressão cantores Euphorionis, a fim de tratar dos

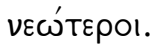

\section{A. RAPAZES}

$\mathrm{Fear}^{21}$ a fim de estabelecer características das personae masculinas na elegia romana, recupera os conceitos de tirocinium adulescentiae (aprendizado da mocidade) e de uacatio adulescentiae (diversão de juventude), compreendidos com base em Sêneca ${ }^{22}$ e em Cícero respectivamente. Antes de tudo, vale dizer que o conceito de adolescentia em Roma difere do nosso, já que lá esse período da vida vai dos 15 aos 30 anos e, assim, corresponderia à nossa ideia de juventude, de mocidade, e não ao período que segue a infância e precede à juventude, como nos dias atuais. Cícero, por exemplo, no Pro Caelio, como está preocupado em associar a imagem de Célio a de um adulescens, constrói sua argumentação a fim de mostrar que no estrato social e na faixa etária a que Célio pertence existem certas açôes que podem ser consideradas "diversão de juventude" 23 - uacatio adulescentiae - ou "deslizes da idade" - perfugia aetatis. Tais açôes estariam, assim, no cerne do conceito de concessa omnibus iura, ${ }^{24}$ isto é, direitos concedidos a todos a que Cícero irá se reportar no discurso como forma de inocentar seu cliente. Ele, Célio, agia encantado pelas libidines da meretrix, ${ }^{25}$ Clodia Metelli, que, segundo Fear, era the malignant erotic influence ${ }^{26}$ para o adulescens. Assim essa mulier o fazia permanecer imerso na nequitia. Cícero, portanto, a partir de um caso específico, desenha uma modus uitae, maneira de ser próprio dos jovens patrícios romanos. Explicita, entretanto, que muitas dessas ações, que são viciosas, serão corrigidas ao longo dos anos, logo não podem ser responsáveis por revelar o caráter definitivo de um uir bonus: ${ }^{27}$
${ }^{19}$ Cic. Orat. 161.

${ }^{20}$ Cic. Tusc. 3.45 .

${ }^{21}$ Fear $(2005,17)$.

${ }^{22}$ Sen., Con. 2.6: Duo

luxuriantur una in domo: alter iuuenis, alter senex; alter filius, alter pater; uterque aeque licenti cultu per publicum incedit.

Alter uobis hoc ait:

'Concessis aetati iocis utor et iuuenali lege defungor; id facio quod pater meus fecit cum iuuenis esset.

Negabit? Bona ego aetate coepi; simul primum hoc tirocinium adulescentiae quasi debitum ac sollemne persoluero, reuertar ad bonos mores.' - Em uma única casa, dois vivem libertinamente: um jovem, outro velho; este é pai, aquele, filho; cada um dos dois caminha

igualmente por lugares públicos com costumes licenciosos. Um deles vos diz: "Usufruo as graças concedidas à juventude $\mathrm{e}$ estou quites com lei da mocidade; assim faço porque meu pai fez quando era jovem. Ele negará? Eu mesmo comecei na idade certa; tão logo eu primeiro tenha cumprido o aprendizado da adolescência, como se fosse uma obrigação e um costume, eu irei retornar aos bons costumes.

${ }^{23}$ Gonçalves (2008, 206).

${ }^{24}$ Concessus iocus aetati em Sen., Con. 2.6.

${ }^{25}$ Leigh (2004, 303-8) propóe uma excelente leitura dos termos adulescens e meretrix no Pro Caelio, tendo em vista as relaçóes já estabelecidas entre esse discurso e a comedia nova grega e romana, já que ambos caracteres são tópicos no cômico. 
${ }^{26}$ Fear (2005, 15).

${ }^{27}$ Manwell (2007, 113): uir bonus is recognizable by distinctive, positive, traditional attributes that are taken to be normative: he is Catonic, stoic, selfcontrolled, self-sacrificing, strong, and excelling in manly deeds. Roman male behavior is prescribed by a complex matrix of positive moral qualities, including disciplina (discipline), pietas (dutiful respect), fides (loyalty), continentia (self-restraint), and, of course, uirtus (manly excellence). Ver Schofield (2009, 199-201).

${ }^{28}$ Cic., Cael. 41.10: "a natureza criou muitos atrativos, aos quais, por vezes, a virtude fecha os olhos, complacente; mostrou à juventude muitos caminhos escorregadios, que esta dificilmente pode pisar e percorrer sem nenhuma queda ou deslize; ofereceu uma grande variedade de coisas agradabilíssimas, com que seduz não só essa idade como também uma já mais resistente". Tradução de Sara Mariana Moreira Maurício.

${ }^{29}$ Cic., Cael. 42.16: Finalmente, depois de ter cedido aos prazeres, de ter dedicado algum tempo às diversōes da idade jovem e às frívolas paixões próprias

da juventude, um dia voltará a interessar-se pelos assuntos domésticos, pelos assuntos do fórum, pelos assuntos públicos, de modo que se veja que as coisas que anteriormente não avaliara racionalmente, as abandonou por enfado
Multa enim nobis blandimenta natura ipsa genuit quibus sopita uirtus coniueret interdum; multas uias adulescentiae lubricas ostendit quibus illa insistere aut ingredi sine casu aliquo ac prolapsione uix posset; multarum rerum iucundissimarum uarietatem dedit qua non modo haec aetas sed etiam iam conroborata caperetur. $^{28}$

Daí amplia seu argumento, ressaltando que se deve ter complacência com os jovens:

Postremo cum paruerit uoluptatibus, dederit aliquid temporis ad ludum aetatis atque ad inanis hasce adulescentiae cupiditates, reuocet se aliquando ad curam rei domesticae, rei forensis reique publicae, ut ea quae ratione antea non perspexerat satietate abiecisse et experiendo contempsisse uideatur. ${ }^{29}$

Cícero completa sua argumentação, propondo uma generalização, ou seja, todos os romanos em sua formação estão sujeitos aos deslizes de conduta, entretanto isto jamais impediu que fossem homens que valorizassem a República e os mores. Parece-me que a posição de Cícero flutua entre opostos, já que, de um lado, ele condena as ações dos delicati e, de outro, minimiza as ações da uacatio adulescentiae. Veyne, reconstituindo o quadro do demi-monde elegíaco, por seu turno, utiliza uma carta de Cícero para justamente mostrar desconforto pessoal do Arpinate com a mauvaise société, ${ }^{30}$ ao ser obrigado a privar da companhia de uma atriz, Volúmnia Citéride, durante um jantar. Afirma categoricamente que a convivência com mulheres deste "tipo" não lhe moveu quando jovem, quanto mais agora depois de velho: me uero nihil istorum ne iuvenem quidem mouit umquam, ne nunc senem. ${ }^{31}$ Dessa maneira, ainda que houvesse por parte de Cícero um interesse profissional no caso de Célio e ele mesmo, nesse sentido, entendesse a dinâmica e funcionamento da sociedade romana; sob a perspectiva de sua vida privada, ele se mantinha distante deste tipo de vida. Entretanto, é curioso observar que ele abre uma concessão à convivência com mulheres do basfonds, quando se é um jovem. Mas é fato que devemos entender que mesmo nessas informaçôes que Cícero apresenta de si, ainda que seja uma carta de caráter privado, 
é ainda uma construção discursiva que está seguramente a serviço da construção do seu próprio î̉os de homem público.

Ainda de acordo com Fear, ${ }^{32}$ o narrador elegíaco, ou o ego-elegíaco é um adulescens aos moldes de um Célio que age em conformidade ao tirocinium adulescentiae senequiano, ou à uacatio adulescentiae delimitada por Cícero. Dessa forma é possível se observar no discurso elegíaco, jâmbico e/ou erótico, dois elementos que devem balizar construção desse narrador: a) delimitação etária ${ }^{33}$ e b) a condição sócioeconômica. Parece-me, entretanto, que a argumentação de Fear a fim de localizar o primeiro elemento soa frágil, levando em consideração a ficcionalidade ${ }^{34}$ elegíaca, já que busca sua sustentação nas elegias tendo em vista as possibilidades biográficas sugeridas em Propércio 4.1B. 131-4 e em Ovídio, Tristia 4.10.58. Não que não possa coexistir auto-referências "biográficas" nesses textos, entretanto essas jamais devem ser observadas sem as devidas aspas, como Freudenburg propôs como chave de leitura para Sermones de Horácio: "Thus, the poet's autobiographical entries into his work I take not as documentary evidence for who he was, but as the first moves of a back-and-forth game played between writer and reader." ${ }^{35} \mathrm{O}$ que não ocorre, a meu ver, na leitura de Fear.

Creio que melhor é adotarmos como argumento favorável à construção do ego-elegíaco jovem, um dado calcado na textualidade do gênero poético em questão, isto é, as inumeráveis circunstâncias em que a ideia de juventude é expressa, decalcada no destinatário preferencial ou quando o próprio narrador se assume jovem em sua atividade poética. Nesse sentido a elegia é realizada por um jovem para um público igualmente jovem. No que se refere ao narrador, em Propércio 3.5.19-20 temos: me iunat in prima coluisse Helicona iunental Musarumque choris implicuisse manus, ${ }^{36}$ ou seja, logo nos primeiros anos da juventude, suponho, portanto, já na adulescentia, o ego-elegíaco não só cultuou o Hélicon, como dançou de mãos dadas às Musas. Em 1.7, também afirma: nec tantum ingenio quantum seruire doloril cogor et aetatis tempora dura queri./ hic mihi conteritur uitae modus, haec mea fama est, / hinc cupio nomen carminis ire mei. ${ }^{37}$ Por outro lado, no que tange ao destinatário, o lugarcomum do epitáfio, parece-me útil nesse caso, pois é e menosprezou pela experiência. Tradução de Sara Mariana Moreira Maurício.

${ }^{30}$ Veyne $(1985,107)$

${ }^{31}$ Cic., Fam. 9.26.2.910: Nada disso, é certo, nunca me moveu jovem, nem agora velho.

${ }^{32}$ Fear $(2005,17)$.

${ }^{33}$ Lopes (2010, passim). A variação de modos elegíacos em Ovídio segue uma ordem cronológica, de sorte que quanto mais velho ele se torna, mais elevada torna-se sua poesia. Assim o caráter, digamos, juvenil apresentado nos Amores contrasta com o mais maduro, por exemplo, nas Pônticas ou nos Tristia.

${ }^{34}$ Martins (2015b).

${ }^{35}$ Freudenburg (2010, 271).

${ }^{36}$ Prop. 3.5.19-20: Alegre-me ter na tenra juventude cultuado o Hélicon/ e ter dado as mãos aos coros das Musas. Ver Conte (2000, 308).

${ }^{37}$ Prop. 1.7.7-10: E sou levado mais a servir à dor e menos ao engenho/ e a lastimar as duras horas da juventude./ Este meu modo de vida transcorre, esta, minha fama,/ Assim desejo que siga a glória de meus poemas. Juventude aqui traduz aetas, a partr do OLD $4 \mathrm{a}=$ youth. Ver Prop. 1.6.21 ou 2.33.33. 
${ }^{38}$ Prop. 1. 7.23-4: E os jovens não poderão se calar diante de meu túmulo/ 'Descanças, ó grande poeta de nosso ardor!'

${ }^{39}$ Prop. 2.3A.33-4: Devo eu hoje admirar que os jovens ardam por ela?/ Tróia, te seria mais belo que moressses por ela.

${ }^{40}$ James (2010, 315).

${ }^{41}$ James (2010, 316). frequente encontrarmos sinalizado nele a quem compete louvar o poeta de amor, que já morreu: nec poterunt iuuenes nostro reticere sepulcrol 'ardoris nostri magne poeta iaces. ${ }^{38} \mathrm{O}$ pentâmetro do dístico ao ser proposto como voz dos jovens inclui o poeta entre os jovens, afinal ele seria o cantor que representa "o nosso ardor", o ardor da juventude que inclui, assim, o próprio poeta. Algo semelhante ocorre em: hac ego nunc mirer si flagrat nostra iuuentus?! pulchrius hac fuerat, Troia, perire tibi. ${ }^{39}$ Ainda que a juventude não seja o interlocutor direto da elegia, é constatada sua reação diante da mulher amada, isto é, os jovens são instados pelo poema.

\section{B. MOÇAS}

Mas que mulher é esta que está exposta na elegia como a contraparte desses adulescentes? Ainda que eu tenha já observado duas personae femininas históricas como as de Clódia e Volúmnia, essas vieram à tona de maneira colateral, já que era minha preocupação observar os jovens do sexo masculino que se coadunassem a um modo de vida "irregular". Há, por exemplo, quem defenda que a puella elegíaca seja uma meretrix, a partir das próprias referências indicadas em seu discurso que é absolutamente coadunado com o das meretrizes de Plauto e de Terêncio de maneira que não nos surpreende que, nesse discurso, encontremos representadas perspectivas e interesses da profissão, em vez de as de uma mulher romana "de família", dedicada à domus, uma matrona. ${ }^{40}$ Sob esse ponto de vista, a posição adotada pela persona da "cortesâ" não revela uma personalidade, mas características de seu ofício, suas interações com seus amantes e clientes e a maneira como se expressa com eles, seu discurso. ${ }^{41}$ Fato é, entretanto, que não há uma equivalência no binômio meretriz - matrona, ou seja, não ser uma meretriz não significa ser matrona. Outras nuanças podem ser encontradas, matizes do feminino podem e devem ser explorados a fim de que o quadro de papéis da elegia se complete. Mas, isto também não significa que a proposição de Sharon James não seja válida, ao contrário, acredito, como iremos ver, que Cíntia e, antes dela Lésbia, são personae que podem e devem ser pensadas como meretrizes, já que é 
justamente dessa maneira que o discurso erótico, por vezes, as apresenta. Ainda assim, é sempre bom ponderarmos que as leituras, que hoje fazemos das representaçōes da mulher, muitas vezes são distorcidas, já que, amiúde, há claras diferenças entre a imaginação e a realidade, inclusive quando se ficcionaliza representações que supostamente podem fornecer dados concretos $^{42}$ e não somente quando, no caminho inverso, procuramos a realidade na ficção.

Horácio em 23 a.C. ${ }^{43}$ curiosamente apresenta um quadro "hiperbolizado" - parece-me - da sociedade romana e, consequentemente, de sua juventude quando foi publicado o terceiro livro de Odes. Tratando da decadência dos mores, o eu-lírico defende que a impiedade e a falta de disciplina familiar causaram a ruína moral de Roma, de sorte que, dos pais de antanho, poder-se-ia esperar somente ações condignas à indisciplina.

fecunda culpae saecula nuptias

primum inquinauere et genus et domos:

hoc fonte deriuata clades

in patriam populumque fluxit.

motus doceri gaudet Ionicos

matura uirgo et fingitur artibus

iam nunc et incestos amores

de tenero meditatur ungui.

mox iuniores quaerit adulteros

inter mariti vina neque eligit

cui donet inpermissa raptim

gaudia luminibus remotis,

sed iussa coram non sine conscio

surgit marito, seu vocat institor

seu navis Hispanae magister,

dedecorum pretiosus emptor. ${ }^{44}$

A virgem desenhada por Horácio contribui para o mapeamento da persona feminina que age na elegia e na poesia erótica. Ela possui um marido libertino, afeito a banquetes e a orgias na madrugada. Ele, por sua vez, admite que sua jovem esposa mantenha relações sexuais com quem
${ }^{42}$ Hallett $(2012,373)$.

${ }^{43}$ Vale lembrar que o primeiro livro de Propércio é de 25 a.C. e o quarto, de 16 a.C.
${ }^{44}$ Hor., Carm.3.6.17-28: Tempos fecundos de males antes sujaram/ as uniōes, depois as casas e as famílias:/ vinda de tal fonte, a ruína fluiu sobre a pátria e as gentes// Uma virgem se alegra precocel de ser experta em danças jônicas/e se modela às essas artes/ e ainda novinha se aplica ao sexo louco.// Sem demora procura jovenzinhos mais tesos,/ entre os vinhos do marido e não elege/ a quem açodado lhe dará,/ gozos proibidos no escuro,// mas surge, bem à vista, mandada,/ não sem que o corno/ saiba, chamando-a o mercador ou o piloto espanhol,/ comprador contumaz de putarias. 
${ }^{45}$ Ainda que o sentido primeiro de matura seja madura, isto é, aquela que

já alcançou seu pleno desenvolvimento, nesse contexto, o sentido é de prematura, precoce. Neste sentido ver Ces., Gal. 4.45 .

${ }^{46}$ McNeill (2001, 108-9) salienta que apesar do tom obscuro e pessimista da ode em questão ela funciona como confirmação do poder de Augusto, isto é, Augusto veio a fim de dar um basta ao estado de coisas apresentado pela ode.

${ }^{47}$ vv. 21-22: motus doceri gaudet Ionicos/ matura uirgo et fingitur artibus.

${ }^{48}$ Maurício (2013, 20-38).

${ }^{49}$ Cic., Cael. 36 e 67.

${ }^{50}$ Cic., Cael. 1. Ou ainda em 70: mulieris libidines et delicias; ou em 78: libidini muliebri.

${ }^{51}$ Cic., Cael. 1, opibus meretriciis; em 38, meretricio more e em 49 , meretricia uita e proterua meretrix procaxque.

${ }^{52}$ Cic., Cael. 32: quam omnes semper amicam omnium potius quam cuiusquam inimicam putauerunt; 38: quae se omnibus peruolgaret; 57: in eius modi domo [...] seruos non esse seruos; 58: istos quoque seruos familiares dominae esse. quer que seja, à vista de qualquer um, inclusive dele. Esse jovem de posses se compraz com venda do corpo de sua mulher, afinal não lhe falta um emptor pretiosus, isto é, um comprador que não se nega a pagar qualquer preço para tê-la. Essa puella, uma uirgo matura ${ }^{45}$ - que ainda há de envelhecer -, tem um $\hat{\eta} \theta 0 s$ que corresponde a uma maneira grega ou "elegíaca" de ser. Isto é, sob o aspecto moral tanto os rapazes em seu tirocinium adolescentiae, como as moças podem agir viciosamente. ${ }^{46}$ Outro elemento, entretanto, que é apresentado poeticamente nesse trecho de Horácio é: assim como os rapazes de alta ordem social devem ter sua educação realizada nas escolas de retórica, as moças também devem ser doctae, ${ }^{47}$ além de serem obviamente devassas, nequam, dado que vivem sob a bandeira da nequitia. Assim as mulheres referidas nessa poesia augustana e na republicana, a que às vezes irei me reportar, estão construídas com base em dois alicerces, um intelectual e, outro, comportamental.

Essas mesmas características fazem-me voltar à Clódia. De acordo com Sara Maurício, ${ }^{48}$ podemos mapear sua persona discursiva de acordo com algumas categorias que servem ao epidítico invectivo. Assim, ainda que esta mulher seja de ordem social elevada, de estirpe inegavelmente distinta (nobilis mulier; e mulieris beatae ac nobilis), ${ }^{49}$ será o alvo de Cícero, a fim de, por contraste, inocentar Célio. Logo no início do discurso, acentua o caráter libidinoso que irá perpassar o discurso (libidinem muliebrem) ${ }^{50}$ ou em 57: in qua inusitatae libidines, luxuries, omnia denique inaudita uitia ac flagitia uersentur. Não são poucas as passagens em que termos associados à venalidade de sua vida sexual é posta a nu, ao utilizar meretrix e meretricius. ${ }^{51}$ Tal atividade, por corolário, a coloca no cerne da promiscuidade..$^{52}$ E Maurício salienta que a qualidade mais bem figurada no discurso é a da desfaçatez:

"com que exibia tal comportamento, sem se preocupar minimamente com as aparências. Assim, é-nos dito que não só não procurava esconder a sua lascívia ( 47 , unius mulieris libidinem esse prolapsam ut ea [...] solitudinem ac tenebras atque haec flagitiorum integumenta non quaerat), como nem sequer se refreava em público, continuando a mostrar-se sedutora e atrevida (49, non nupta mulier domum suam patefecerit omnium cupiditati 
palamque sese in meretricia uita conlocarit [...], si hoc in urbe, si in hortis, si in Baiarum illa celebritate faciat [...] ut non solum meretrix, sed etiam proterua meretrix procaxque uideatur)..$^{53}$

Parece-me, entretanto, que o discurso de Cícero, ainda que possibilite a inclusão de Clódia entre as mulheres de família nobre, não é eficaz para consolidar historicamente o outro aspecto importante, porque complementar ao da devassidão, aquele que, sob a perspectiva ciceroniana, deveria ser valorizado: o da puella, ou da femina docta. Nesse sentido, me parece que o retrato possível e interessante a ser verificado é o da Semprônia de Salústio. Essa assim como, aquelas duas, mesmo que sejam construçốes discursivas a serviço de suas textualidades específicas, valorizam algo que não é intrinsecamente associável à devassidão: o viés intelectual. Mesmo que atrizes e dançarinas não sejam um exemplo de virtude para esta sociedade, Sêneca num coro de Agamêmnon diz: tibi fila mouent docta puellael carmine molli, "as jovens vibram doutas cordas,/ num carme melodioso", ${ }^{54}$ assim nesse caso o caráter douto, está longe de ser intrinsecamente associado à vida viciosa de uma femina. Entretanto, na Semprônia de Salústio, tem-se lado-a-lado características morais baixas ligadas ao caráter douto:

mulieres (...) quae primo ingentes sumptus stupro corporis tolerauerunt, (....) Sed in eis erat Sempronia (...) Haec mulier (...) litteris graecis latinis docta, psallere et saltare elegantius quam necesse est probae, multa alia quae instrumenta luxuriae sunt (...) lubido sic acensa ut saepius peteret uiros quam peteretur. ${ }^{55}$

Wike acertadamente observa que a elegia augustana representa seu herói como um homem fiel à sua amada que é sempre desleal. Apesar desta oposição inicial entre lealdade

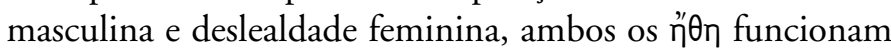
em espelho, uma vez que, se ele está sempre engajado na metáfora da servidão sexual e da guerra erótica, absolutamente fora de suas obrigações civis, portanto; ela, por sua vez, atua fora dos papéis convencionais de esposa e de mãe romana, ${ }^{56}$ agindo mais em conformidade com î̉ $\hat{\jmath}$ os de uma cortesã do que com o de uma matrona. Nesse sentido, pode-se inferir, analogamente ao homem elegíaco, a existência de uma
${ }^{53}$ Maurício (2013, 22).

${ }^{54}$ Sen., Ag. 360-361. Tradução de José Eduardo dos Santos Lohner.

${ }^{55}$ Sal., Cat. 24-25.

Mulheres que, a princípio, tinham sustentado grandes despesas com o comércio de seus corpos (...) 25 .

Entre elas estava

Semprônia (...). Essa mulher (...). Instruída nas letras gregas e Latinas, tocava cítara, dançava com mais elegância do que convinha a uma mulher de bem; muitos outros dotes que são auxiliaries da devassidão. Tradução de Antônio da Silveira Mendonça.

${ }^{56}$ Wike (2002, 34-5). 
King (1976, 70); Pomeroy (1995); Balsdon (1962). Contra Gibson (2005, 162) e Wike (2002, 42-43): It is not the concern of elegiac poetry to upgrade the position of women, only to portray the male narrator as alienated from positions of power and to differentiate him from other, socially responsible male types

(...) generally elegiac metaphors are concerned with male servitude not female mastery.

${ }^{58}$ Johnson (2012, 40): Briefly, that revolution had its origins in a

fragmentation of social institutions that took place while its political institutions were being demolished; at the core of the erotic ideology that fueled this revolution was a profound distrust of and an increasing indifference to traditional ideas about sex and marriage and family values that had obtained in Rome for most of its known history. Ver Hallett (2012, 373).

${ }^{59}$ Martins (2009).

${ }^{60}$ Wike (2002, 36).

${ }^{61}$ Martins (2009, 129-140). recusatio matronae, ou seja, uma mulher romana que se recusa a cumprir e seguir o modus uitae, um papel negociado tradicionalmente nessa sociedade.

É comum observar que, apesar da dissonância semântica existente entre alguns tipos de representação do feminino, a mulher elegíaca pode se constituir como uma representação poética de um "movimento de liberação sexual da mulher como um símbolo de uma nova liberdade". ${ }^{57}$ Ainda que essa posição de King soe-me pouco útil e anacrônica, a compreensão destes $\eta^{\prime} \theta \eta$ femininos como reflexos de uma nova circunstância social romana em coadunação com o novo momento político de transição entre a República e o Império parece-me bem razoável. ${ }^{58}$ Assim a mulher elegíaca (Cíntia, Délia, Corina, Licóride), assim como a Lésbia da coleção de Catulo, têm suas nuanças também desenhadas na Clódia do Pro Caelio e na Semprônia da Coniuratio Catilinae. Porém, ainda assim, este exemplário feminino não é o retrato instantâneo da nova mulher sob a perspectiva de um documento vivo da realidade, é, antes, a

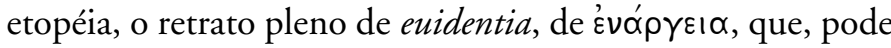
sim, verossimilmente, conferir fides aos discursos elegíacos, ${ }^{59}$ líricos, iâmbicos, históricos e forenses. Wike assim bem sinaliza que a Semprônia de Salústio e a Clódia de Cícero têm frequentemente sido empregadas como evidência de uma "New Woman": Yet it is important to observe that, even outside the poetic sphere, our principal evidence for the lives of ancient women is still on the level of representations, not realities. ${ }^{60}$

No entanto, mesmo que as representações femininas (na história e na oratória, de um lado e, na poesia elegíaca, polimétrica, de outro lado) possam encontrar pontos de contato, estabelecendo uma relação intergenérica (genre e não gender), há que se notar que se, muita vez, por exemplo, Cíntia é invectivada por Propércio, ${ }^{61} \mathrm{em}$ outras tantas ela é o alvo de um discurso laudatório. O que, de forma semelhante, a meu ver, ocorre com a Lésbia de Catulo que, em poucos poemas, é pintada cercada de tantos e muitos beijos e também sofre violentas agressões verbais em outros. Assim, esta duplicidade de representação feminina de um mesmo objeto, muito além de uma simples alteração de humor, parece-me apontar para uma "banal" pluralidade 
de sentimentos a que estão sujeitos um homem e uma mulher em suas vidas amorosas. Logo, a poesia oferece um lugar de expressão fictícia a relações existentes nesse mundo concreto.

É justamente essa questão que impõe uma natureza dúbia - fronteiriça - à produção poética erótica, possibilitando a expressão plural de sentimentos que é operada no limite entre ficção e realidade. ${ }^{62}$ Griffin já argumentava que muitos estudiosos menosprezaram os poetas augustanos em certos aspectos importantes, porque se pensou, em princípio, ser possível separar "literatura" e "vida", como se fossem entidades claramente distinguíveis; porém, um afeta o outro em uma interação mútua, de sorte que motivos poéticos e comportamento real estiveram sempre inextricavelmente imiscuídos. ${ }^{63}$ Entretanto, vale dizer que tal afirmação não significa que são dados biográficos que devam ser observados e extraídos dessa poesia.

\section{IMERSOS NA NEQUITIA}

Tendo, em certa medida, mapeado os agentes preferenciais da poesia erótica, isto é, moças e rapazes de vida abastada e a relação entre ações concretas e ficcionais da quais essa poesia é devedora, devo considerar o ambiente em que as ações libidinosas desses mesmos agentes. Ainda que Catulo não utilize um termo recorrente, específico para devassidão, como é o caso de nequitia em Propércio ${ }^{64} \mathrm{e}$ Ovídio, ${ }^{65}$ é certo que a ideia de vida devassa está presente em alguns de seus poemas, logo não posso deixar de lhe atribuir necessária posição sobre esta questão na poética elegíaca. Suas referências à vida libidinosa, luxuriosa e promíscua são construídas para inserir as personae nequam, ${ }^{66}$ agindo em sua coleção de poemas. Da mesma maneira que agentes de ações viciosas guardam estreita relação com certos gêneros literários no final da República e no começo do Principado, como vimos a partir de alguns exemplos, é possível também associar o conceito de nequitia poética a um concreto ambiente devasso, conhecido em Roma e nas Províncias no período, uma maneira de ser comum, ou mesmo, vulgar a esta sociedade. Por exemplo, Propércio
${ }^{62}$ Martins (2015b).

${ }^{63}$ Griffin (1976, passim).

${ }^{64}$ Prop. 1.6.26; 1.15.38;

$2.5 .2 ; 2.6 .32 ; 2.24 .6$

$3.10 .24 ; 3.19 .10$.

${ }^{65}$ Ov., Am. 2.1.2;

$3.1 .17 ; 3.4 .10$;

3.11b.37; 3.14.17; Ov., Ep. 4.17; 17.29; Ov., Ars 2.392; Ov., Fast. 1.414; Ov., Trist. 2.1.280.

${ }^{66}$ Cic., Cael. 10: Ad quem si accessit aut si a me discessit umquam quamquam multi boni adulescentes illi homini nequam atque improbo studuerunt - tum existimetur Caelius Catilinae nimium familiaris fuisse. Se alguma vez se aproximou dele ou se afastou de mim - se bem que muitos jovens bem formados se tenham afeiçoado a esse homem vil e desprezível então pode imaginar-se que Célio foi bastante íntimo de Catilina. Tradução de Sara Mariana Moreira Maurício. 
${ }^{67}$ Ver Cic., Cael. 27; 35; 38; 47 e 49 .

${ }^{68}$ Sen., Ep. 5.51.1: quia illum sibi celebrandum luxuria desumpsit.

${ }^{69}$ Sen., Ep. 5.51.1: Baias quidem: deversorium uitiorum esse coeperunt.

${ }^{70}$ Sen., Ep. 5.51.4: Que necessidade tenho eu de ver bêbados caminhando à beira-mar aos baldóes, as orgias de barco ou de lagos ecoando com cantos e orquestras, de ver, enfim, todo o desregramento que a vida de prazer faz gala em cometer e ostentar? Tradução de J. A. Segurado e Campos.

${ }^{71}$ Prop. 1.11.24: “Tu és todos os meus momentos de deleite”.

${ }^{72}$ Prop. 1.11.27-30: "Assim, o quanto antes, saia da devassa Baias:/ Esta praia separou muitos casais,/ Praia que foi, que é inimiga de meninas puras:/ Que sequem as águas de Baias, crime de amor."

${ }^{73}$ OLD, 1: Moral corrupting or perverting. c. enticement to sexual misconduct. 2. A source of corruption; b. a brothel. Ver Cic. Cat.

1.13 . propõe uma elegia ambientada na pequena cidade litorânea de Baias, ${ }^{67}$ cujas antigas referências, digamos, não são abonadoras dos boni mores. Cidade situada na baía de Nápoles, reconhecida por suas termas, é tratada por alguns autores como uma cidade que deve ser evitada, "porque se transformou num lugar onde reina a vida de prazer", ${ }^{68} \mathrm{ou}$, porque a cidade "está transformada num autêntico antro de vícios". ${ }^{69}$ Sêneca, enfim, resume o modus uitae de alguns frequentadores de Baias, posicionando-se peremptoriamente de forma contrária ao local:

Videre ebrios per litora errantes et comessationes navigantium et symphoniarum cantibus strepentes lacus et alia quae uelut soluta legibus luxuria non tantum peccat sed publicat, quid necesse est? ${ }^{70}$

Pois é justamente em Baias que Propércio apresenta Cíntia afastada do ego-elegíaco e, nesse sentido, esse a interpela questionando se sua paixão a faz se lembrar dele à noite; se ainda há espaço para ele em seu coração; se alguém, talvez um novo amante, lhe roubou de suas elegias. Conclui que sem os devidos cuidados uma puella está sempre sujeita à infidelidade. Tudo isto como forma de justificar que o local em que Cíntia está é determinante de ações devasssas. Assim, confirma finalmente que Cíntia é "omnia tu nostrae tempora laetitiae, ${ }^{, 71}$ finalizando a elegia da seguinte maneira:

tu modo quam primum corruptas desere Baias:

multis ista dabunt litora discidium

litora quae fuerunt castis inimica puellis:

ah pereant Baiae, crimen amoris, aquae! ${ }^{72}$

Assim há efetivamente uma "nequitia histórica" relacionada com a "nequitia elegíaca", isto é, uma maneira de ser comum, um uitae modus do alto segmento social que podia se reunir em saraus e orgias na madrugada na urbs, nas domi, como também nas uilae prouinciarum no litoral. Por outro lado, sob a perspectiva de uma nequitia ou corruptela ${ }^{73}$ histórica, por assim dizer, Griffin, por exemplo, afirma que Marco Antônio é um modelo de homem de a 
ação e de prazer - in uniting the man of pleasure and the man of action -, ou seja, um homem que simultaneamente adere às responsabilidades civis e participa de todas as esferas de prazer que Roma pode oferecer. Nesse sentido, representa um tipo de vida glamorosa, ao contrário de Otávio que, assim que se torna Augusto (em 27 a.C.), busca apagar "a imagem anti-augustana" de Júlio César. ${ }^{74}$

Curiosamente, quando Marco Antônio serve no Egito, sob Aulo Gabínio, se une à Volúmnia Citéride (a mesma a que me referi na carta de Cícero anteriormente). Ela, também devemos lembrar fora amante de Cornélio Galo, e isto brings him into pleasingly intimate connection with the elegiac poets; and his life as we see it in the late 40's and 30's is one of nequitia and amours. ${ }^{75}$ Cícero dá um sinal bem interessante acerca do $\hat{\eta} \theta 0$ s de Marco Antônio em uma das Filípicas, ao lembrar que certa vez ele chega à noite em casa, disfarçado de mensageiro com uma carta de amor - amatorie scripta - dirigida à Fúlvia em que promete abandonar sua amante e ser fiel a ela, agindo assim, Marco Antônio estaria absolutamente de acordo ao îं de uma persona elegíaca, afinal para sua atitude, Cícero precisamente exclama: "O hominem nequam?"76

No início do Monobiblos, entre as elegias 1 e 6, Propércio define claramente quais elementos lhe são necessários como material poético para a consecução de sua narrativa elegíaca. Assim, em 1.1 apresenta Cíntia e o amante submisso, o ego-elegíaco; ${ }^{77}$ em 1.2, constrói visualmente Cíntia e sua estreita intimidade com o luxo, dado importante na elaboração de seu $\hat{\eta} \theta 0$; em 1.3 , desenha o amante, o ego-elegíaco em atividade noturna, velando o sono da amada, desnudando seus desejos ${ }^{78}$ em 1.4 , apresenta um primeiro rival, um tertius, ${ }^{79}$ Basso que também é um rival literário em gênero iâmbico; ${ }^{80} \mathrm{em} 1.5$, é indicado um segundo rival, Galo, igualmente literário, que deseja usufruir dos amores de Cíntia. A elegia 1.6, dirigida a Tulo, desenvolve a tópica da recusatio amoris, ingrediente importante na formação do gênero elegíaco, ${ }^{81}$ contudo além dessa apresentação tópica, nela está delineado pela primeira vez em Propércio o ambiente preferencial da elegia; o ambiente em que as ações das personae elegíacas soem decorosamente aos leitores:
${ }^{74}$ Ramage (1985, 223224): "the emperor from the beginning of his rise to power carried out a subtle program of propaganda designed to suppress Caesar and to put a distance between himself and his father."

${ }^{75}$ Griffin (1977, 22).

Tratando de Cic. Phil. 2.44, Manwell (2007, 115) propõe: "His portrayal of Antony as decadent and soft is tied inextricably to what Cicero sees as his moral and political failings.

Mollitia is not an excuse, but an analysis: surely a man this degenerate and wrong-headed must desire to engage in the worst of sexual depravities."

${ }^{76}$ Cic., Phil. 2.77. Griffin (1977, 22).

${ }^{77}$ Fantham (2006, 184): "she is the woman desired, cruel and unyielding, like Atalanta (1.1.10 saevitiam durae... Iasidos), because she imposes demands on the man who seeks to be her lover."

${ }^{78}$ Wike (2002, 14); Greene (1998, 519)

${ }^{79}$ Ainda que a ideia do rival seja explicitamente apontada no Livro I, nominando-os, Propércio aponta um bons versos para esse intento, Prop. 1.11.7-8: an te nescio quis simulatis ignibus hostis/ sustulit e nostris, Cynthia, carminibus?. - $\mathrm{Ou}$ desconheço um rival que roubou te robou, Cíntia,/ de minha elegias, com um fogo dissimulado?

${ }^{80}$ Heslin $(2011,52)$; Martins (2015c). 
${ }^{81}$ Fantham (2006, 184): This book confines itself within a tight male circle (Tullus, Gallus, Bassus, Ponticus) - themselves introduced in terms of their misguided indifference to love

(Ponticus, 1.7, reversed in 1.9), their criticism of Cynthia (Bassus 1.4), or jealous attempts to seduce her (Gallus 1.5).

${ }^{82}$ Prop. 1.6.25-8: Deixa que eu a quem a Fortuna sempre quis prostrado,/ Dedique minha alma para sempre a essa devassidão./

Muitos morreram com prazer num longo amor,/

Entre eles, que a terra também me cubra.

${ }^{83}$ Assumo livro 2. 2A, elegias de 1-11 e 2B, elegias de 12-34, portanto adiro à hipótese de divisão do livro 2, ainda que existam pequenas diferenças sobre quais fossem as elegias: inicial do livro $2 \mathrm{~B}$ e final de $2 \mathrm{~A}$. Por exemplo, Fantham (2006, 186): "What we have as the second book is both the most discontinuous and the most complex of

his books; it is almost certainly a fusion of two previous collections, with a second beginning at

2.10 sed tempus lustrare aliis Helicona choreis." Ver Lachmann (1816), Hubbard (1974), Skutsch (1975), Goold (1990)

11-12, Lyne (1998a), (1998b), Murgia (2000), Heyworth (2007), Martins (2015a) entre outros. me sine, quem semper uoluit fortuna iacere,

huic animam extremam reddere nequitia;

multi longinquo periere in amore libenter,

in quorum numero me quoque terra tegat. ${ }^{82}$

A nequitia que, sob a ótica ciceroniana, é apresentada como viciosa, já que denota as ações de um nequam, surge neste contexto como desejo a ser conquistado, ou seja, o ego-elegíaco, assumindo a condição imposta pela Fortuna, isto é, jazendo, reivindica também que sua alma seja encaminhada rumo à devassidão. Logo, ainda que, sob o ponto de vista ético a nequitia soe viciosa, textualizada na elegia romana, assume valor positivo, uma vez que: a) é expressão do desejo do enunciador; b) é uma vontade divina - Fortuna; e c) possui um aspecto transitório para esses rapazes e moças, ao que tudo indica - como já foi visto. Assim, já que o corpo está afeito inexoravelmente ao otium e à inertia, afinal ele jaz, que alma se dedique a ações próprias do jovem nequam que fazem com que num longo amor muitos possam morrer e entre estes ele mesmo, o egoelegíaco. Parece-me que o tripé: otium, inertia e nequam/ nequitia estão na base das recusationes amoris. Um dado curioso dessa formulação é a dicotomia corpo e alma, estabelecendo uma relação de consequência entre a inertia e a nequitia, que fora já apontada anteriormente por Griffin, como vimos. E também a relação, aparentemente, inconsistente entre o primeiro e o segundo dístico, dado que no primeiro há a nequitia e no segundo há o amor. Conclusivamente posso compreender, portanto, que a nequitia entre os elegíacos ou, pelo menos em Propércio, pode ser alcançada em plena relação amorosa.

Ao se observar o îtos do enunciador das elegias de Propércio, que somente em 2A.8.1783 será nominado, Propertius, pode-se notar a proximidade entre essa construção poética e as referências concretas como as de Célio, ou mesmo, as de Marco Antônio, com as quais trabalhei há pouco, ainda que este e aquele tenham indubitavelmente como norte o cursus honorum, e, portanto, não possam ser exemplares quanto à recusa da vida civil em nome da vida amorosa (recusatio amoris). É justamente esse ponto de diferenciação que pode ser lido como um dos índices da 
ficcionalidade operada na elegia romana. Assim, ao sobrepor uma maneira de ser "elegíaca" ou grega ao nomen real e concreto Tibullus, ${ }^{84}$ Propertius $^{85}$ e Naso, ${ }^{86}$ ou mesmo, antes deles Catullus, ${ }^{87}$ o poeta elegíaco aponta seu discurso para a fronteira - realidade e ficção $-^{88} \mathrm{em}$ que se dá a narração elegíaca.

Por outro lado, as elegias do Livro 2A de Propércio parecem-me essenciais para a amplificação do $\hat{\eta} \theta 0$ de Cynthia, dado que ao seu espectro de ação somam-se outras possibilidades. Ela já é não apenas a amada do ego-elegíaco, ou apenas uma puella cobiçada por vários homens (amigos/ rivais), inclusive outros poetas (Galo, Basso, ou Pôntico), ${ }^{89}$ ou apenas uma moça refinada e bela comparável a heroínas concorrentes nos mitos como as figuradas no Livro 1. É uma Cynthia que será amplificada ao longo das próximas elegias já nos é claramente indicada nos dísticos que fecham a primeira elegia do segundo livro: seu nuda erepto mecum luctatur amictu, / tum uero longas condimus Iliadas: / seu quidquid fecit siuest quodcumque locuta, I maxima de nibilo nascitur historia. ${ }^{90}$ Cíntia, portanto, retratada nua com o ego-elegíaco em cada ato sexual dará razão de existência a "longas...Iliadas"; seja lá o que ela diga ou faça, isto irá se transformar numa "historia". Cíntia a partir desse ponto não é só o alvo de elegias, antes convém também ao gênero épico e ao histórico. É óbvio sem esquecermos que esta afirmação faz parte do discurso elegíaco - irônico, por excelência - e como tal deve ser considerada. Mais do que isso Cíntia, já que se observada discursivamente, ela está a serviço de uma narratio, seja lá qual for o gênero. É-me certo que Propércio narrativamente universaliza o îं0os de Cíntia, no Livro 2A, fazendo-o ascender genericamente, fazendo-o exceder o $\hat{\eta} \theta 0 s$ previamente modulado no Monobiblos. Diante disso, a pergunta que nos resta é bem simples. Mas, como isto será realizado discursivamente?

$\mathrm{Na}$ terceira elegia do livro dois, temos o seguinte dístico: Si quis uult fama tabulas anterire uetustas, / his dominam exemplo ponat in arte meam ${ }^{91}$ que a meu ver, sintetiza a construção de Cíntia que pode ser analisada a partir de uma bricolagem de retratos parciais realizados em 1.3.1-8; 1.15.9-22; 2A.1.4-16; e que virá ser completado em 2B.28.15-24.
${ }^{84}$ Tib. 1.3 .55

${ }^{85}$ Prop. 2.8.17.

${ }^{86}$ Ov., Am. 1.11.27.

${ }^{87}$ Catull. 6.1.

${ }^{88}$ Martins (2015b)

${ }^{89}$ Heslin $(2011,52)$; Martins (2015b).

${ }^{90}$ Prop. 2A.1.13-16: Ou se, ao tirar a roupa, nua, luta comigo,/ Então componho longas Ilíadas./ E seja o que tenha feito, seja o que tenha dito,/ Do nada nasce a maior história.

${ }^{91}$ Prop. 2A.3A.41-42. Se alguém quer superar a fama de antigas pinturas/ tome nesta arte minha mulher como exemplo. 
${ }^{92}$ Prop. 2A.3A.25-28:

Os deuses te conferiram celestes dons, assim,/ Não creias que te foram dados por tua mãe/Tais dotes não, não são produtos humanos:/ Dez meses não produziriam tamanhos bens.

${ }^{93}$ Prop. 2A.3A.29. gloria Romanis una es tu nata puellis.

${ }^{94}$ Catull. 58: Caeli, Lesbia nostra, Lesbia illa,/ illa Lesbia, quam Catullus unam/ plus quam se atque suos amauit omnes, /nunc in quadriviis et angiportis/glubit magnanimos Remi nepotes. - Célio, a minha Lésbia, Lésbia, aquela, / aquela Lésbia só a quem Catulo / mais do que a si amou, mais do que aos seus, / hoje costuma em becos e quadrívios / filhos de Remo descascar magnânimo. Tradução de João Angelo Oliva Neto.

${ }^{95}$ Fantham (2006, 187).

${ }^{96}$ Pomeroy (1995, 92).
Entretanto, é certo que uma hipérbole já fora produzida em relação a ela:

haec tibi contulerunt caelestia munera diui, haec tibi ne matrem forte dedisse putes. non, non humani partus sunt talia dona: ista decem menses non peperere bona. ${ }^{92}$

Logo, Cíntia não é uma beleza natural, ela não foi parida por uma mãe, nasceu dos deuses, mas não aqueles a que estamos acostumados a ler em narrativas míticas ou nas teogonias. São de outro jaez. Deuses a serviço da experiência textual e sexual, da produção poético-discursiva do amor, aqueles que permitem que ela seja uma representação hiperbolizada na elegia, uma construção poética que fará com que ela, Cíntia, seja uma glória nascida entre as meninas de Roma; ${ }^{93}$ ela será a primeira puella romana a deitar-se com Júpiter e irá, assim, obrigatoriamente preterir o ego-elegíaco, Propertius. A universalização do $\hat{\jmath} \theta 0$ s de Cíntia é paradoxalmente sua vulgarização, seu rebaixamento a uma outra condição moral, porquanto mais importante, entretanto viciosa. Ela, amante, não serve mais a um único adulescens - Propertius, quem sabe -, serve aos romanos, como que os fazendo retornar ao mito de origem de Aca Laurência. Ainda que a vulgarização de Lésbia em Catulo $58,{ }^{94}$ por exemplo, não a associe a um mito esta mantém uma estreita semelhança com aquela. Esta glubit os netos de Remo e aquela será a primeira romana a copular com Júpiter. Após este anúncio, Propércio em 2A.4 aponta os efeitos do amor malfadado sobre o narrador, logo indica o ego-elegíaco imerso num morbus amor. Fantham, por exemplo, afirma que enquanto o primeiro livro reafirmava a escravidão do poeta a Cíntia e evocava sua beleza e seus talentos, o segundo livro amplia o contexto, aplicando direta e indiretamente Cíntia em circunstâncias claramente profissionais associadas ao tipo da hetaera grega conhecida dos romanos por conta das comédias de Plauto e Terêncio. ${ }^{95}$ Nesse sentido, podemos entender melhor um matiz preciso da mulher elegíaca, já que a hetaera não pode ser identificada como uma simples prostituta uma vez que além de seus dotes físicos e sexuais, é extremamente hábil com a flauta e a lira, sabe dançar e cantar. ${ }^{96}$ 
Já a elegia 2A.5, tem-se a confirmação concreta da vulgarização de Cíntia, afinal: Hoc uerum est, tota te ferri, Cynthia, Roma, / et non ignota uivere nequitia? ${ }^{37}$ Assim não é só o adulescens elegíaco que vive em plena devassidão, mas sua puella na narrativa passou a também viver. Dormiu com Júpiter, o pai de todos os deuses e homens. Cíntia passa a ser uma metonímia da meretrix, uma verdadeira lupa, o que curiosamente a se levar em conta a textualidade erótica não é nenhum demérito, haja vista a própria afirmação de Propércio: nil patrium nisi nomen habet Romanus alumnus:/ sanguinis altricem non putet esse lupam. ${ }^{8}$ Assim como não seria, portanto, depreciativo o jovem amante chamar de perfida, vadia (v. 3) e a ameaçando que encontrará outras jovens igualmente fallaces, devassas (v.5) entre as quais uma que fieri nostro carmine nota uelit. ${ }^{99}$ Em seguida, alertando Cíntia como um verdadeiro praeceptor amoris, finaliza:

scribam igitur, quod non umquam tua deleat aetas,

'Cynthia, forma potens: Cynthia, uerba leuis.' crede mihi, quamuis contemnas murmura famae, hic tibi pallori, Cynthia, uersus erit. ${ }^{100}$

Assim, mesmo que o ego-elegíaco supostamente devesse agir inconsequentemente, movido pela devassidão programática de um tirocinium adulescentiae, este busca na infidelidade da amada, na devassidão em que está imersa, um amor quase ingênuo. Aqui o ego-elegíaco parece-me distanciar de seus modelos concretos - histórico-oratórios. Mas há um elemento verificável a partir desta ingenuidade quase romântica avant la lettre, o fato de este amante ser um poeta e esse dato nos é fundamental. Sua arma contra as iniquidades desta devassa, por ora configurada na narrativa, é seu texto, sua poesia elegíaca que ganha, vez por outra, nítidos contornos jâmbicos.

Tanto isto é razoável que a elegia 2 A.6 em seus três primeiros dísticos para caracterizar a vulgarização de Cíntia, a compara às três maiores prostitutas gregas. Laís, Taís e Frina são inferiores na devassidão se comparadas à Cíntia:
${ }^{97}$ Prop. 2A.5.1-2: É verdade o que está na boca de Roma, Cíntia, a saber, que vives em explícita devassidão?

${ }^{98}$ Prop. 4.1.37-38: O novo nada tem de romano senão o nome pátrio,/ não recrimina que a lupa alimentou seu sangue.

${ }^{99}$ Prop. 2A.5.6: há de quer se tornar famosa com minhas letras. Tradução de Paulo Martins.

${ }^{100}$ Prop. 2A.5.27-30: Eu escreverei, pois, o que em tua vida nunca se apagará:/ "Cíntia , beleza ingente; Cíntia diversão, palavras"./ Crê-me, ainda que desprezes os boatos $\mathrm{da}$ fama,/ Esses versos, Cíntia, vão te deixar pálida. 
${ }^{01}$ Prop. 2A.6.1-6: Não vinham assim à casa de Laís de Éfira,/ em cuja porta curvou-se toda

Grécia;/Nem outrora for a tamanha turba à de Taís de Menandro/ Na qual brincou o povo de Erictônio; / Nem Frina, que pôde refazer Tebas destruída,/ Tornou-se rica por ter tantos homens.

${ }^{102}$ Prop. 2A.6.27-30: Qual foi a primeira mão pintou obscenas quadros/ E pôs em casta casa torpes visōes,/ Essa corrompeu os ingênuos olhos das meninas e, rude,/ Quis que elas conhecessem a sua devassidão.
Non ita complebant Ephyraeae Laidos aedes, ad cuius iacuit Graecia tota fores; turba Menandreae fuerat nec Thaidos olim tanta, in qua populus lusit Ericthonius; nec, quae deletas potuit componere Thebas, Phryne tam multis facta beata uiris. ${ }^{101}$

Mais do que uma comparação com prostitutas helenísticas tópicas, há a superação de Cíntia em relação às atividades de cada uma, de maneira que à casa de Cíntia vão mais homens do que à de Laís para a qual "toda a Grécia" tinha ido; igualmente supera Taís em cuja residência "todo o povo de Atenas" brincou e, finalmente, seu status econômico ultrapassa o de Frina que sozinha reconstruiu Tebas com o dinheiro recebido de seus clientes. Cíntia, portanto, é pintada como uma profissional do sexo, muito semelhante à uirgo matura de Horácio. Ela é um verdadeiro êmulo em relação a esses tipos figurados na tradição helenística. Os exemplos de beleza e de virtude associados a ela no primeiro livro, neste são trocados pela ação viciosa da nequitia, entretanto mais adiante nessa elegia Propércio busca as causas dessa desfaçatez feminina - vale lembrar de Clódia no Pro Caelio. Quem teria conduzido moças como Cíntia para a vida da devassidão? Sua conclusão é inusitada: as mãos dos artistas que primeiro pintaram "cenas obscenas" é a resposta. Essa mão corrompeu os ingênuos olhos das meninas e quis que elas conhecessem a devassidão. Pareceme que nesse ponto, Propércio apresenta o vício endemicamente, isto é, Cíntia é aquilo que muitas meninas em Roma são, assim como, Semprônia, Clódia e Volúmnia, ou Lésbia, Licóride, Cíntia e Délia.

quae manus obscenas depinxit prima tabelas

et posuit casta turpia visa domo,

illa puellarum ingenuos corrupit ocelos

nequitiaeque suae noluit esse rudis. ${ }^{102}$ 


\section{A PUELLA COMO METÁFORA E O ADULESCENS COMO} COROLÁRIO

Nas páginas precedentes tracei um perfil referencial da poesia erótica, observando uma base documental que pudesse assentar tanto a construção das personae poeticae, que agem na narrativa poética a que se subordina nessa textualidade específica, como também um ambiente no qual sua maneira de ser pudesse ser decorosamente constituída. Daí ter verificado a maneira grega ou "elegíaca", ou "erótica" de ser de jovens do final da República e do início do Principado, além de seu ambiente de atuação discursiva em que seus papéis soassem verossímeis, o da nequitia. A referencialidade deve, assim, constituir um elemento importante para um estudo de poesia antiga, já que se encarrega de oferecer os liames que esta poesia mantém com o mundo coetâneo que a cerca e com uma forma mentis que é capaz de decodificar as prescriçôes e convençôes dos gêneros poéticos. Portanto esse elemento, isto é, a referencialidade, contribui para que tenhamos clareza de fatores essenciais numa narrativa que possam nos levar a dizer que o texto foi construído verossimilmente e que fora capaz produzir fides, afecção importante já que se encarrega de produzir a nebulosidade necessária entre ficção e realidade no jogo poético. Entretanto, se a poesia for apenas referente, ela deixa de ser poesia, já que a função de sua linguagem é diversa à da própria poesia, ou simplesmente outra, ou, aristotelicamente, deixa de imitar aquilo que poderia ser e passa a imitar aquilo que foi, deixa de ser a representação daquilo que poderia suceder e passa a ser a representação daquilo que sucedeu, deixa de ser universal e passa a ser particular. ${ }^{103}$ Nesse sentido, Wike já propôs que entender a escrita dessa poesia como um happening amoroso concreto é, em certa medida, negligenciar, ignorar o caráter poético da produção artística. ${ }^{104}$ Ainda propõe que esta poesia não se associa a um caso concreto do poeta, mas sim a "grammar of his poetry". ${ }^{105}$ Entre as questôes que podem envolver a linguagem poética, tem-se o uso polissêmico de alguns termos que resultam a produção de tropos como a metáfora, a alegoria, a metonímia, a sinédoque, a hipérbole, entre outros que ainda segundo a estudiosa fazem despontar
103 Arist., Po. 1451a 36$1451 \mathrm{~b} 11$.

${ }^{104}$ Wike $(2002,14)$.

${ }^{105}$ Wike (2002, 17). 
${ }^{106}$ Liveley (2010, 212).

${ }^{107}$ Ov., Ars 1.611: Tu deves agir como amante $\mathrm{e}$ as feridas devem ser imitadas por suas palavras.

${ }^{108}$ Kennedy (2008, 22). uma mulher escrita, uma scripta puella, fundada por sua gramática poética e a serviço dela. Tomemos Cíntia e Lésbia, pois creio que ambas não se limitam a serem a contraparte feminina do ego-elegíaco, Propertius, de um lado, ou do enunciador de poemas, Catullus, de outro, como convenções poéticas; têm muito a nos informar uma, porquanto, discursos que são, estão plenamente engatadas a outras formas discursivas do período.

Além disso, mais uma questão deve ser revitalizada: o papel da estrutura narrativa proposta nesses poemas, pois como já anotei a base de minha argumentação consiste na análise de elementos poéticos inerentes à sua própria escrita, à sua própria "gramática", narrativa e poeticamente observável. Ainda que eu mesmo concorde com grande parte das teses de Veyne (1985), em pelo menos um ponto dele divirjo, já que o historiador não vê uma estrutura narrativa nos poemas de Propércio, dado que não possuem uma estrutura típica de uma história de amor. Nesse sentido, Veyne, inusitadamente, dá as mãos a Boucher (1965) que também entendia que não havia começo e fim análogo a uma novela no primeiro livro e o segundo livro é completamente independente de uma cronologia semelhante a de uma novela. Ocorre, no entanto, que ambos buscam nesses poemas marcas ortodoxas da narração, cuja estrutura é fixa e rígida. Liveley, nesse sentido, precisamente informa: Yet theories of narrative show that even without action or plot, without telos or denouement, without continuity or chronology, both poets and readers can, and do, endow such poems with narrative meaning. ${ }^{106}$ Sob a perspectiva da poesia erótica - e a Ars Amatoria é marco essencial - nós podemos observar explicitamente - o subgênero é erotodidático - a função do praeceptor amoris como participante e guia de açôes eróticas de seu leitor, assim ele assume um papel proativo na textualidade elegíaca: est tibi agendus amans imitandaque uulnera uerbis. ${ }^{107}$ A narrativa na poesia erótica não se restringe a uma rigidez dos mecanismos ortodoxos, antes os extrapola, principalmente, quando podemos observar nela um posicionamento do ego-elegíaco nas ações que estão sendo apresentadas, advertindo os leitores que eles podem internalizar o papel, participando do jogo, fingindo ser aquilo que não são. ${ }^{108}$ 
Quando falamos das meninas amadas - puellae - na elegia romana ou na poesia erótica, devemos continuamente suspeitar que elas não são exclusivamente o assunto ou o destinatário da poesia, ou seja, não são apenas aquilo do que se fala ou aquela com que se fala na poesia, mesmo porque a narrativa elegíaca é descontínua, características assumidas num momento podem ser absolutamente desmentidas num momento seguinte, assim elas são também a própria poesia também naquilo que há de divergência entre elas. Logo quando os poetas falam das amadas, falam de "fazeres poéticos. Assim, ao se observar os poemas de

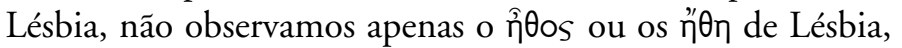
mas também a coleção de poemas associados à Lésbia, o mesmo ocorrendo Cíntia. Um bom argumento, como alerta Gibson, decorre do próprio nome que as amadas recebem. De um lado, Cíntia, Délia e Licóride, são nomes associados a Apolo, o deus da poesia, além de Corina e Lésbia manterem conexão direta com poetas gregas, ${ }^{109}$ de sorte que esses nomes centrais, Cíntia e Lésbia, na poesia de Propércio e Catulo, por metonímia, são o próprio nome de suas poesias. Ainda que a informação apresentada por Apuleio, ${ }^{110}$ associando esses nomes a personae históricas em Roma, transformandoos em pseudônimos, não seja algo confiável sob a perspectiva poética, isto é, jamais serão reais, uma vez que são poesia, a própria indicação de que são nomes atribuídos imprimem neles mesmos intencionalidade ficcional e metapoética. Entretanto, parece-me definitiva a compreensão foucaultiana de que na origem tudo tinha um nome - o nome próprio ou singular que progressiva e articuladamente passa a atuar junto de outras coisas que não são as originais e daí surgirem as figuras como a sinédoque, metonímia e a catacrese, ou mesmo, a metáfora se bem que a analogia é menos imediatamente sensível. ${ }^{111}$ Diz Foucault que a unidade sólida e cerrada da linguagem é aquela que:

pelo jogo de designação articulada, faz entrar a semelhança na relação proposicional. Quer dizer, num sistema de identidades e de diferenças, tal como é fundado pelo verbo ser e manifestado pela rede de nomes. A tarefa fundamental do "discurso" clássico consiste em atribuir um nome às coisas e com esse nome nomear o seu ser. ${ }^{112}$
${ }^{109}$ Gibson (2005, 166).

${ }^{110}$ Apul., Apol. 10.

${ }^{111}$ Foucault $(1990,131)$. 
${ }^{113}$ Hor., Carm. 1.26.9-

12: Sem ti os meus louvores nada podem:/ a ti e às irmãs tuas cumpre agora/ a este consagrar em novas cordas, /a este em Lésbio plectro. Tradução de Elpino Duriensee.

${ }^{114}$ Hor., Carm. 4.6. 3536: guardai o Lésbio ritmo e os sons, que fere/ o meu polgar na lira. Tradução de Elpino Duriense.

${ }^{115}$ Hor., Carm. 1.32.4-6: possa viver, ó lira,/ que Lésbio cidadão tocou primeiro. Tradução de Elpino Duriense.

${ }^{116}$ Ov., Tr. 3.7.19-20: Se ainda remanessem igualmente os fogos de teu peito/ Somente a poeta Lésbia vencerá tua obra.

${ }^{117}$ Ov., Am. 3.1.5-10:

Hic ego dum spatior tectus nemoralibus umbris/ (Quod mea, quaerebam, Musa moueret opus),/Venit odoratos Elegeia nexa capillos,/ Et, puto, pes illi longior alter erat;/ Forma decens, uestis tenuissima, uultus amantis, / Et pedibus uitium causa decoris erat. Aqui, eu enquanto vagava, oculto pelas sombras do bosque/ (pois buscava um gênero que a Musa inspirasse), / eis que chega a Elegia, com cabelos cheirosos e trançados /e, acho, tinha um pé mais longo do que o outro. /A bela forma era decente; a vestimenta, muitíssimo tênue; o rosto, de amante:/

E o defeito nos pés era causa do decoro. (Tradução de João Angelo Oliva Neto e Paulo Martins).

${ }^{118}$ Lukács (1971, 83-149).
Lésbia, portanto, antes de ser o nome da amada no(s) Livro(s) de Catulo também deve ser entendida, como uma representante, um vetor poético em Catulo cuja linhagem está explícita no poema $51 \mathrm{com}$ a tradução de Safo, por exemplo. Há que se observar também as referências pósteras operam o conceito. Horácio, por exemplo, associa Lésbio a um tipo de ritmo: nil sine te meil possunt honores. hunc fidibus nouis, / hunc Lesbio sacrare plectro/ teque tuasque decet sorores ${ }^{113}$ ou em, Lesbium seruate pedem meique/pollicis orti. ${ }^{114}$ Essa referência a Lésbio como "fôrma" poética de maneira mais específica também irá aparecer associado a Alceu em barbite, carmen,/ Lesbio primum modulate ciui ${ }^{115}$ e à Safo em Ovídio: Ergo si remanente ignes tibi pectoris idem,/ Sola tuum uates Lesbia uincet opus. ${ }^{116}$

Outra possibilidade para Lésbia é entendê-la como uma Musa, uma das doctae sorores. Nesse sentido pareceme que Catulo nos oferece uma boa indicação quando nos apresenta na sua dedicatória no v.9 o vocativo "o patrona uirgo" e em 2.1, o aposto para "passer", "deliciae meae puellae" e a dona do passarinho em 3.3 e a mea Lesbia no poema 5. Assim, creio que haja aqui uma sobreposição semântica e paradigmática, a deusa virgem, a minha menina e minha Lésbia são as mesmas personae com que o poeta há de "brincar" nas próximas nugae. Entretanto, a ideia de tratar a destinatária da poesia como musa parece-me muito distante de uma metáfora, antes é uma relação explícita entre o conteúdo e o continente, logo uma metonímia, relativamente simples. Falar que Cíntia e Lésbia são as musas das poesias de Propércio e Catulo respectivamente e, portanto, são seus próprios livros de poesia é algo trivial. Ocorre, porém, que a partir desta construção óbvia e trivial, Propércio já no segundo poema do Monobiblos, portanto, logo após o anúncio de seu programa poético em 1.1, sugere índices metalinguísticos materializados ou persoalizados como que produzindo ou uma prosopopeia da poesia,,${ }^{117}$ ou uma reificação de Cíntia. Ainda que soe anacrônica esta possibilidade - a da reificação - já que pode ser associada a uma visão marxista de Verdinglichung, revisitada por Lukács, ${ }^{118}$ não tenho essa preocupação com esse possível viés, penso, antes, a reificação ou coisificação como uma simples operação de figuração que proporciona a transformação de 
algo animado em coisa, no caso: Cíntia em poesia, como uma operação inversa da prosopopeia ou da personificação que consiste na transformação de algo inanimado em ser animado, ampliando, portanto, as suas possibilidades de nomeação. Diz Propércio:

Quid iuuat ornato procedere, uita, capillo et tenuis Coa veste mouere sinus, aut quid Orontea crines perfundere murra, teque peregrinis uendere muneribus, naturaeque decus mercato perdere cultu, nec sinere in propriis membra nitere bonis? crede mihi, non ulla tua est medicina figurae: nudus Amor formam non amat artificem. ${ }^{119}$

Quando Propércio opta produzir um vocativo no primeiro verso, "uita", isso me parece muito importante, uma vez que indica uma ambiguidade programática que tanto serve a sua função profissional, aquela que lhe dá seu sustento, sua poesia, ou apenas, uma amplificação de sua amada, Cíntia, que acabara de ser apontada no poema anterior como essencial a sua produção poética - sua Musa. Fato é que opta pela ambiguidade deste termo nesse contexto. O mesmo verso produz outro dado poético importante, agora intertextual e metalinguístico: se considerarmos "cabelos enfeitados" como simplesmente o cabelo de Cíntia, temos um dado referencial; mas se entendermos que isso é uma alusão poética cujo tema é o cabelo da amada, temos imediatamente a indicação a dois poetas significativos para Propércio: Calímaco ${ }^{120}$ e Catulo ${ }^{121}$ e, nesse sentido, o cabelo ornado ${ }^{122}$ é a própria poesia elegíaca produzida em moldes helenísticos, em cuja composição o ornamento é virtude da elocução. Outro ponto a ser observado é o fato de a "vida" caminhar com cabelos ornados. Propércio, a meu ver, indica o desenvolvimento escrito da sua própria poesia; essa caminha e se desenvolve (estamos no início do Monobiblos), envolta em uma tênue veste, numa roupa transparente que é o limite de uma metáfora compreensível, aquela em que os indicadores de compressibilidade são acessíveis àqueles que comungam da mesma forma mentis, dessa maneira a roupa diáfana torna o
${ }^{119}$ Prop. 1.2.1-14: De que te serve, vida, andar com cabelos ornados /E ondular tênues trajes de Cós /Ou espargir com mirra de Orontes os cabelos/ E aparecer com mimos estrangeiros/ $\mathrm{E}$ perder seu decoro natural com luxo comprado/ E não deixar brilhar o corpo com seus dons?/ Crê-me, tua beleza não carece de cosméticos:/ O Amor nu não ama artifícios de beleza.

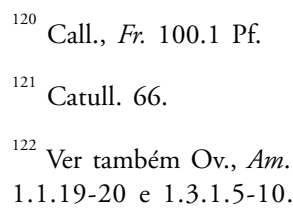


${ }^{123}$ Hor., Ars 75.

${ }^{124}$ Hor., Ars 77-78: quis tamen exiguos elegos emiserit auctor,/ grammatici certant et adhuc sub iudice lis est. -

Qual autor, entretanto, teria produzido antes exíguas elegias,/os gramáticos disputam e até hoje, a demanda está sub judice. Quint., Inst.

10.1.93: Elegia quoque Graecos provocamus, cuius mihi tersus atque elegans maxime videtur auctor Tibullus. Sunt qui Propertium malint. Ovidius utroque lascivior, sicut durior Gallus Quanto à elegia nós também rivalizamos com os gregos, dessas o autor Tibulo parece-me muito mais esmerado e elegante. Há quem prefira Propércio. De um lado, Ovídio é mais afetado, assim como Galo, mais grosseiro.

${ }^{125}$ Quint., Inst. 10.93: Satura quidem tota nostra est - A sátira na verdade é toda nossa.

${ }^{126}$ Prop. 2.5.1-2: Isto é verdade o que está na boca de Roma, Cíntia,/ E que vives em aberta devassidão? verso mais compreensível. A matéria é de Cós, terra de Filetas, um terceiro indicador metalinguístico do poema, sem esquecermos a mirra de Orontes que se ocupa do odor erótico da poesia sinestesicamente. O odor e o sabor da poesia são os da mulher. É digno de lembrança que as dobras da veste, o "sinus", apontam para o próprio movimento da escrita, a idas e vindas do verso e do reverso e do movimento e do ritmo do dístico, de versos "impariter". ${ }^{123}$ Há que se lembrar que o mesmo movimento impresso à roupa e ao verso não pode ser apartado da própria forma curvilínea da mulher que pode ser observada pela transparência das vestes de Cós. Diante disso tudo, entretanto, esta mulher, esta poesia, é vendida, tendo em vista luxos peregrinos. Metalinguisticamente a poesia elegíaca, de acordo com Horácio e Quintiliano, ${ }^{124}$ não é um fenômeno poético tipicamente romano, como por exemplo, a sátira. ${ }^{125}$ Não só Cíntia pode ser comprada, como também a poesia, já que é uma mercadoria, de sorte que tanto uma como outra, poesia e mulher, são venais, são vulgares e populares. Propércio dissimula, contudo, a tese da beleza natural, uma vez que está sempre aplicado na artificialidade da poesia. A beleza de Cíntia não carece de cosméticos referencialmente, entretanto, a poesia operada por ele é toda ela fundada na artificialidade.

O dístico inicial de 2 A.5 sobre o qual me debrucei há pouco, sinaliza a comunhão entre duas imagens de Cíntia: Hoc uerum est, tota te fieri, Cynthia, Roma, / et non ignota uinere nequitia? ${ }^{26}$ A polissemia Cíntia apresenta consequências importantes. Num primeiro sentido temos que: a) Cíntia é afamada, conhecida, pois está na boca de todos em Roma; b) Cíntia vive em assumida devassidão, isto é, suas atividades são condizentes a uma nequam. Tomando a persona Cíntia como uma amante, ou uma meretriz - o que se confirma na narrativa nos seis primeiros versos do poema 2A.6 -, em ambos os casos significa, ao que parece, um vitupério, sua fama é mala fama, vulgar, impudica, venal. $\mathrm{O}$ fato de viver sob a égide da nequitia do segundo verso, portanto, confirma a afirmação e acrescenta, a meu ver, um componente de promiscuidade, afinal poderia ser ela afamada e não ser promíscua, mas a devassidão imprime uma componente vituperiosa. 
Mas, Cíntia é definitivamente poesia e o fato de estar na boca de Roma significa ser declamada por todos na cidade, é um livro popular, o Monobiblos, afinal o segundo livro está sendo escrito, portanto sua fama só pode advir do livro predecessor. O livro lido é o livro manuseado, um livro que indistintamente é manipulado por muitas pessoas o que implica, portanto, uma "promiscuidade positiva". Ser tocado, ser desenrolado, ser lido por muitos aponta para a sua vulgarização e popularização, logo afeito ao mundo devasso de inúmeros donos e donas que o(a) compraram. Assim o primeiro sentido dos primeiros versos de $2 \mathrm{~A} .5$ aponta para um lado do epidítico que é o vitupério e o segundo sentido aponta para o laudatório. Se Cíntia é uma meretriz, como já vimos em 2A.6, isto significa dizer que ela como livro produz benefícios pecuniários a quem a produziu, elegia; além de produzir a bona fama, viés, portanto, inverso ao da mala fama que já observamos.

Parece-me também necessário observar o antepenúltimo verso Cynthia, forma potens: Cynthia, uerba leuis (v.28). Afinal é óbvia sua estrutura paralela que põe lado-a-lado as duas "Cíntias": a Cíntia-amada, forma potens e a Cíntia-palavras, isto é, uerba, uma clara indicação à Cíntia-poesia, livro, portanto. Pelo OLD leuis, cujo referente é Cynthia, pode ter o sentido de suave, leve, entretanto pode ter o sentido de inconstante $(\mathrm{OLD}, 15)$, ao se referir a pessoas, mas ao se unir a Cíntia-palavras devemos, retirar o referente do âmbito das "pessoas" e, colocá-lo no âmbito discursivo e, dessa forma, parece-me que o sentido de "intended for amusement" (OLD, 14), isto é, "destinada à diversão" se coaduna ao próprio jogo poético proposto programaticamente para a elegia. Nesse sentido, vale entender que as ações de Cíntia são próprias ao ludus, ao iocus, Cynthia, uerba leuis, é apropriada ao sexo à diversão da vida devassa, do uitae modus elegíaco. Essa construção poética, portanto, revela gnomicamente a própria condição discursiva de Cíntia.

Um pequeno exemplo dessa popularização ou vulgarização de Cíntia, sob o ponto de vista material e referencial, é um grafite encontrado em Pompéia (CIL, IV 4491). Ainda que August Mau, no século 19, proponha uma visão de arte como arte oficial e monumental, já que enfatiza a exiguidade de informaçôes contidas nesses meios ou a 


\footnotetext{
${ }^{127}$ Mau (1899, 482-3).

${ }^{128}$ nunc est ira recens nunc est disc[edere tempus]/ si dolor afuerit crede redibit

[amor] - Hoje a ira é recente, hoje é tempo de separação:/ Se a dor se for, crê, o amor tornará. Ver Mau (1899, 485).
}

pouca importância das expressões "populares", uma vez que essas nada dizem sobre os homens "que desejaríamos conhecer", desprezando, sob o aspecto histórico, índices da vida cotidiana, ainda assim ele afirma categoricamente que com eles, os grafites, "ganhamos uma ideia viva de gostos, paixões e experiências pessoais". ${ }^{127}$ Dessa maneira, como não poderia deixar de ser, o tema mais comum nesse meio, o grafite, é o amatório e, nesse sentido, ele pode refletir ou representar uma forma mentis daqueles a quem se destinam e de quem falam as elegias. Explicitamente o scholar afirma que algumas das linhas são retiradas de poetas cujo verso é o dístico elegíaco; outros foram feitos para uma ocasião especial, e não poucos dísticos foram adaptados, como se o candidato a poeta, tomando contato com a composição original, notou que realizá-la é muito mais difícil do que ele imaginava. Seja como for, a abundância desses grafites de amor evidenciam a popularização dessa fórmula poética - a elegia, de sorte que a vulgarização de Cíntia saiu da boca do ego-elegíaco e ganhou as paredes de Pompéia, e, quem sabe, também de Baias, Herculano e, obviamente, de Roma. O CIL IV, 4491 coincidentemente reproduz os versos 9-10 da elegia 2A.5:128

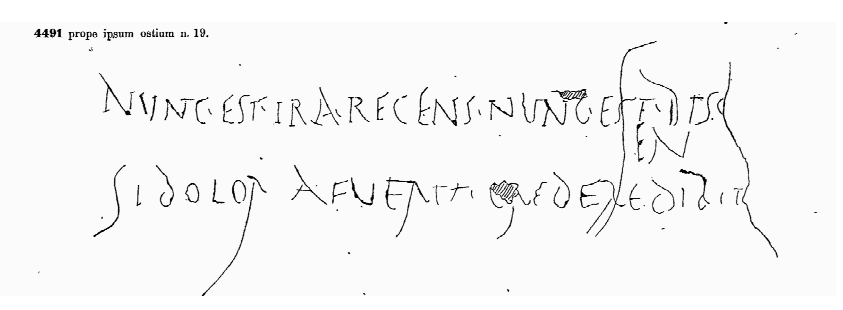

CIL IV 4491

Logo aquilo de que se ocupa a elegia sob o ponto de vista da constituição de sua persona feminina, sua vulgarização ocorre também historicamente sob o ponto de vista da materialidade dos versos de Propércio, de seu livro, de sua Cíntia. Assoma-se a esta estrutura narrativa singular um contraponto metafórico importante, o papel da lena. 


\section{A mulher e a poesia COMO SUSTENTO - Conclusóes}

Mesmo que metaforicamente Cíntia seja o livro, se a pensarmos referencialmente como meretrix, é necessário que ela tenha o auxílio de uma lena, isto é, de uma alcoviteira, de uma cafetina a servir o agenciamento de sua atividade econômica. Myers ${ }^{129}$ apresenta uma hipótese para esta persona recorrente em Ovídio, Tibulo e Propércio. ${ }^{130}$ Afirma que sob o aspecto poético ela é o êmulo do praeceptor amoris, assumido discursivamente na textualidade elegíaca e erótica. Isto seria motivado pelo fato de ela fazer a prédica de um código erótico, calcado na própria elegia cujo enunciador privilegiado não é ela, mas o poeta-amator ou ego-elegíaco. No entanto, referencialmente ela é necessária, logo se impóe à puella como instrutora erótica e, consequentemente, poética a fim de que a verossimilhança do discurso seja garantida. Assim, como é prerrogativa da narratio que o preceptor descreva e construa o amante adequado, a lena póe em risco o poeta, o desafia textualmente, afinal ela também faz seus carmina, entretanto esses são capazes de produzir a impotência sexual, portanto incapacidade poética. Tanto isto faz parte da elegia como prerrogativa genérica que todos três poetas elegíacos a amaldiçoam, a lena, denunciando principalmente seus poderes mágicos malévolos, seus carmina, que são dirigidos contra eles e seus exiguos elegos - uma invectiva explícita, portanto. A disputa, assim, mais do que sexual e venal, é discursiva, a fim de que se tenha e se estabeleça diante dos leitores quem detém afinal o poder sobre os uerba.

Ainda que o papel da lena seja o papel da puella uetusta, com a vênia do oximoro, e, assim, o ego-elegíaco perca seu interesse e passe a disputar com ela a nou a puella, a nova poesia de novos poetas novos, posso dizer que sob a perspectiva da narrativa elegíaca, a lena é a voz de uma mulher na elegia como contraposição à voz masculina do poeta, sem aqui entrarmos em considerações de gênero, gender, digo. Entretanto, se do ponto de vista discursivo a puella é meretriz e poesia, o poeta, obrigatoriamente, além de poeta-amator, é também cafetão, proxeneta, rufião como a persona lírica da ode 3.6 de Horácio que, como vimos, 
busca para sua mulher, sua musa - talvez sua nova poesia, uma uirgo matura -, um emptor pretiosus, ele busca para Cíntia um melhor preço. Ele a deseja falada por toda Roma, para que lhe renda mais dividendos do que Laís, Taís e Frina.

A conclusão a que podemos chegar a partir do estabelecimento dessas relações referenciais e poéticas que se apresentam na elegia e na poesia erótica romana são: 0)a) Cíntia, Lésbia, Délia ou Corina são a amada ou a meretriz e a própria poesia; b) a nequitia é ambiente decoroso às ações dessas mulheres e seus pares; c) no decurso das narrativas eróticas e/ou elegíacas elas sofrem um processo de vulgarização e/ou popularização poética e/ou moral que podem ser lidos referencial ou poeticamente e d) esta estrutura de constituição das personae, esta estrutura poética, nos encaminha ao entendimento da proposição de T. S. Eliot quando, comparando a poesia de Catulo e de Propércio com a de Virgílio, diz: Catullus and Propertius seem ruffians. Ainda que Eliot tenha apenas detratado a poesia de ambos, Catulo e Propércio, por uma óbvia, clara preferência poética, isto é, a fim de elevar a poesia de Virgílio, posso dizer que acerta precisamente na tradução da alegoria que o conjunto da narrativa/ do discurso elegíaco de Propércio e da poesia erótica romana descortinam. Assim Cíntia e Lésbia, mais do que musas, amadas ou poemas são o eco-chave de preceitos poético-eróticos que estão na base de uma fronteira discursiva que foi articulada genericamente em Roma sob a rubrica da elegia ou de um enigma que estamos empenhados em decifrar.

\section{BIBLIOGRAFIA}

BALSDON, J. P. V. D. Roman Woman: Their History and Habits. London: The Bodley Head, 1962.

BOUCHER, J-P. Études sur Properce: problèmes d' inspiration et D'art. Paris: de Boccard, 1965.

CONTE, G. B. A Humorous Recusatio: On Propertius 3.5. CQ 50.1: 307-310, 2000. DOI: http://dx.doi.org/ $10.1093 / \mathrm{cq} / 50.1 .307$. 
DYSON, J. T. The Lesbia Poems. In SKINNER, M. $A$ Companion to Catullus. Malden \& Oxford: Wiley \& Blackwell, 2007. p. 254-275. DOI: http://dx.doi.org/ 10.1111/b.9781405135337.2007.00016.x.

FANTHAM, E. The Image of Woman in Propertius' Poetry. In GÜNTHER, H.-Ch. Brill's Companion to Propertius. Leiden: Brill, 2009. p. 183-98. DOI: http://dx.doi.org/ 10.1163/9789047404835_009.

FARRELL, J. Calling out the Greeks: Dynamics of the Elegiac Canon. In GOLD, B. K. A Companion to Roman Love Elegy. Malden \& Oxford: Wiley \& Blackwell, 2012. p. 11-24. DOI: http://dx.doi.org/10.1002/9781118241165.ch1.

FEAR, T. The Poet as Pimp: Elegiac Seduction in the Time of Augustus. Arethusa, 33.2:217-240, 2000. DOI: http:// dx.doi.org/10.1353/are.2000.0009.

FEAR, T. Propertian Closure. In ANCONA, R.; GREENE, E. (eds.). Gendered Dynamics in Latin Love Poetry. Baltimore: The Jonhs Hopkins University Press, 2005, p. 13-40. URI: http://oro.open.ac.uk/id/eprint/9263.

FOUCAULT, M. As Palavras e as Coisas. São Paulo: Martins Fontes, 1990.

FREUDENBURG, K. Horatius Anceps: Persona and Self revelation in Satire and Song. In DAVIS, G. A companion to Horace. Malden \& Oxford: Wiley \& Blackwell, 2010: DOI: $10.1002 / 9781444319187 . c h 14$.

GIBSON, R. Love Elegy. In HARRISON, S. A Companion to Latin Literature. Malden \& Oxford: Blackwell, 2005, p. 159173. DOI: http://dx.doi.org/10.1002/9780470996683.ch12. GONÇALVES, J. M. T. O poeta, a amada e o rival: contributos para um retrato. Classica, 21.2, p. 205-220, 2008. DOI: http:/ /dx.doi.org/10.14195/2176-6436_21-2_4

GOOLD, G. P. Propertius. Elegies. Loeb Classical Library. Cambridge, Mass.: Harvard University Press, s/d.

GREENE, E. Elegiac Woman: Fantasy, Materia , and Male Desire in Propertius 1.3 and 1.11. AJPh,116.3, p. 30318, 1995b. DOI: http://dx.doi.org/10.2307/295446. 
GREENE, E. The Erotics of Domination: Male Desire and the Mistress in Latin Love Poetry. Baltimore: Johns Hopkins University Press, 1998.

GREENE, E. (2000). Gender Identity And The Elegiac Hero In Propertius 2.1. Arethusa 33.2 p. 241-261, 2000. DOI: http://dx.doi.org/10.1353/are.2000.0010.

GRIFFIN, J. Augustan Poetry and the Life of Luxury. JRS 66, p. 87-105, 1976. DOI: http://dx.doi.org/10.2307/ 299782.

GRIFFIN, J. Propertius and Antony. JRS 67, p. 17-26, 1977. DOI: http://dx.doi.org/10.2307/299915.

HALLETT, J. P. Women in Augustan Rome. In JAMES, S. L.; DILlON, S. (2012). A Companion to Women in the Ancient World. Oxford: Blackwell, 2012. DOI: http:// dx.doi.org/10.1111/b.9781405192842.2012.00041.x

HESLIN, P. Metapoetic Pseudonyms in Horace, Propertius and Ovid. In JRS 101, p. 51-72, 2011. DOI: http:// dx.doi.org/10.1017/S0075435811000062.

HEYWORTH, S. J. Cynthia. A Companion to the Text of Propertius. Oxford: OUP, 2007.

HUBBARD, M. Propertius. London, 1974.

JAMES, S. L. Introduction: Constructions of Gender and Genre in Roman Comedy and Elegy. Helios 25, p. 1-16, 1998.

JAMES, S. L. Learned Girls and Male Persuasion: Gender and Reading in Roman Love Elegy. Berkeley: California University Press, 2003.

JAMES, S. L. 'Ipsa Dixerat': Women's Words In Roman Love Elegy. Phoenix 64.3/4, p. 314-344, 2010. DOI: http:/ /dx.doi.org/10.2307/23074749

JOHNSON, W. R. Propertius. GOLD, B. K. A Companion to Roman Love Elegy. Malden \& Oxford: Wiley \& Blackwell, 2012. p. 39-52. DOI: http://dx.doi.org/ 10.1002/ $9781118241165 . c h 3$. 
KENNEDY, D. Elegy and the Erotics of Narratology. In LIVELEY, G.; SALZMAN-MITCHELL, P. Latin Elegy and Narratology: Fragments of Story. Columbus: The Ohaio Syate University Press, 2008, p. 19-33.

KING, J. K. Sophistication vs. chastity in Propertius' Latin love elegy. Helios, 4, p. 67-76, 1976.

LACHMANN, K. (ed.). Sexti Aurelii Propertii Carmina. Leipzig: Teubner, 1816.

LANGLANDS, R. Sexual Morality in Ancient Rome. Cambridge: Cambridge University Press, 2006.

LEIGH, M. The Pro Caelio and Comedy. CPh, 99.4, p. 300-335, 2004. URL: http://www.jstor.org/stable/ $10.1086 / 429939$.

LIVELEY, G. Cynthia prima fuit, Cynthia finis erit: Time and Narrative in Propertius 4. Helios, 37.2, p. 111-127, 2010. DOI: http://dx.doi.org/10.1353/hel.2010.0005.

LOPES, C. G. Confluência genérica na Elegia Erótica de Ovídio ou a Elegia Erótica em elevação. Dissertação de Mestrado. São Paulo, Universidade de São Paulo, 2010. URL: http://www.teses.usp.br/teses/disponiveis/8/8143/ tde-03032010-133009/pt-br.php

LUKÁCS, G. Reification and the Consciousness of the Proletariat. In History and Class Consciousness: Studies in Marxist Dialectics. Translated by Rodney Livingstone. Cambridge, Mass: MIT Press: 1971. p. 83-149.

LYNE, R.O.A.M. Propertius 2.10 and 11 and the Structure of Books '2a' and '2b'. JRS, 88, p. 21-36, 1998a. DOI: http://dx.doi.org/10.2307/300803.

LYNE, R.O.A.M. Introductory Poems in Propertius 1.1 and 2.12. PCPhS, 44, p. 158-81, 1998b. DOI: http:// dx.doi.org/10.1017/S006867350000225X.

MCNEILL, R. L. B. Horace Image, and Identity. Baltimore: Johns Hopkins University Press, 2001.

MANWELL, E. Gender and Maculinity. In SKINNER, M. A Companion to Catullus. Malden \& Oxford: Wiley \& Blackwell, 2007. p. 111-138: DOI: http://dx.doi.org/ 10.1002/9780470751565.ch7 
MARTINS, P. Elegia Romana: Construção e Efeito. São Paulo: Humanitas, 2009. DOI: http://dx.doi.org/ 10.13140/2.1.3644.9605

MARTINS, P. Ekphrasis, Digression and Elegy: Propertius 2.12. (2015a: texto inédito).

MARTINS, P. O jogo elegíaco: fronteiras entre a cultura material ou intelectual e a ficção poética DOI: http:// dx.doi.org/10.13140/RG.2.1.3535.7608 (2015b: artigo inédito - sob referee).

MARTINS, P. Rumor, lei e elegia: considerações sobre Propércio, 2.7 DOI: http://dx.doi.org/10.13140/ RG.2.1.1110.9285 (2015c: artigo inédito - sob referee).

MAU, A. Pompeii. Its Life and Art. Translated by Francis W. Kelsey. New York: Macmillan, 1899.

MAURÍCiO, S. M. M. Cícero em Defesa de Célio. Dissertação de Mestrado. Coimbra: Universidade de Coimbra, 2013. URI: http://hdl.handle.net/10316/23960.

MILLER, P. A. The Puella: accept no substitutions! In THORSEN, T. S. (ed.). The Cambridge Companion to Latin Love Elegy. Cambridge: Cambridge University Press, 2013. p. 166-79. DOI: http://dx.doi.org/10.1017/ CCO9781139028288.015.

MURGIA, C. E. (2000). The Division of Propertius 2. $M D$, 45, p. 147-252, 2000. DOI: http://dx.doi.org/ $10.2307 / 40236186$.

MYERS, K. S. (1996). The Poet and the Procuress: The Lena in Latin Love Elegy. JRS 86, p. 1-21, 1996. DOI: http://dx.doi.org/ http://dx.doi.org/10.2307/300420.

POMEROY, S. B. Goddesses, Whores, Wives, and Slaves: Woman in Classical Antiquity. New York: Schocken Books, 1995.

RAMAGE, E. S. Augustus' Treatment of Julius Caesar. Historia: Zeitschrift fu"r Alte Geschichte, 34. 2, p. 223245, 1985. URL: http://www.jstor.org/stable/4435922

SALLES, C. Nos Submundos da Antiguidade. Trad. de Carlos Nelson Coutinho. São Paulo: Brasiliense, 1982. 
SCHEIN, S. L. 'Our Debt to Greece and Rome': Canon, Class and Ideology. In HARDWICK, L.; STRAY, C. A companion to classical receptions. Malden \& Oxford: Wiley \& Blackwell, 2008. p. 76-85. DOI: http://dx.doi.org/ 10.1002/9780470696507.ch6.

SCHOFIELD, M. Republican Virtues. In BALOT, R. K. A companion to Greek and Roman political thought. Malden \& Oxford: Blackwell, 2009. p. 199-213. DOI: http:// dx.doi.org/10.1002/9781444310344.ch13.

SHARROCK, A. Constructing Characters in Propertius. Arethusa, 33.2, p. 263-84, 2000. DOI: http://dx.doi.org/ 10.1353 /are.2000.0013.

SKUTSCH, O. The Second Book of Propertius. HSCP 79, p. 229-33, 1975.

VASCONCELOS, P. S. de Catulo, O Cancioneiro de Lésbia. São Paulo: Hucitec, 1991.

VEYNE, P. A Elegia Erótica Romana. São Paulo: Brasiliense, 1985.

WYKE, M. Written Woman; Propertius'scripta puella. JRS, 77, p. 47-61, 1987a. DOI: http://dx.doi.org/10.2307/ 300574 .

WYKE, M. The elegiac woman at Rome. PCPhS, 33, p. 153-78, 1987b. DOI: http://dx.doi.org/10.1017/ S0068673500004971.

WYKE, M. Roman Mistress: Ancient and Modern Representations. Oxford: Blackwell, 2002. 